\title{
Future Research Directions on the "Elusive" White Shark
}

\section{OPEN ACCESS}

Edited by:

Mark Meekan

Australian Institute of Marine Science

(AIMS), Australia

Reviewed by:

Nuno Queiroz,

Centro de Investigação em

Biodiversidade e Recursos Genéticos

(CIBIO), Portugal

Gail Schofield,

Queen Mary University of London,

United Kingdom

${ }^{*}$ Correspondence:

Charlie Huveneers

Charlie.huveneers@flinders.edu.au

Specialty section:

This article was submitted to

Marine Megafauna,

a section of the journal

Frontiers in Marine Science

Received: 29 July 2018 Accepted: 13 November 2018 Published: 17 December 2018

Citation:

Huveneers $C$, Apps $K$ Becerril-García EE, Bruce B, Butcher PA, Carlisle AB, Chapple TK, Christiansen HM, Cliff G, Curtis TH,

Daly-Engel TS, Dewar H, Dicken ML, Domeier ML, Duffy CAJ, Ford R,

Francis MP, French GCA, Galván-Magaña F,

García-Rodríguez E, Gennari E,

Graham B, Hayden B,

Hoyos-Padilla EM, Hussey NE, Jewell OJD, Jorgensen SJ, Kock AA,

Lowe CG, Lyons K, Meyer L,

Oelofse G, Oñate-González EC

Oosthuizen H, O'Sullivan JB,

Ramm K, Skomal G, Sloan S,

Smale MJ, Sosa-Nishizaki O,

Sperone E, Tamburin E, Towner AV, Wcisel MA, Weng KC and Werry JM (2018) Future Research Directions on

the "Elusive" White Shark.

Front. Mar. Sci. 5:455.

doi: 10.3389/fmars.2018.00455
Charlie Huveneers ${ }^{1 *}$, Kirin Apps ${ }^{2}$, Edgar E. Becerril-García ${ }^{3,4}$, Barry Bruce ${ }^{5}$, Paul A. Butcher 6 , Aaron B. Carlisle ${ }^{7}$, Taylor K. Chapple ${ }^{8}$, Heather M. Christiansen ${ }^{9,10}$, Geremy Cliff 11,12, Tobey H. Curtis ${ }^{13}$, Toby S. Daly-Engel ${ }^{14}$, Heidi Dewar ${ }^{15}$, Matt L. Dicken 11,16, Michael L. Domeier17, Clinton A. J. Duffy'8, Richard Ford19, Malcolm P. Francis ${ }^{20}$, Georgia C. A. French ${ }^{21,22}$, Felipe Galván-Magaña ${ }^{3}$, Emiliano García-Rodríguez ${ }^{23}$, Enrico Gennari24,25,26, Brittany Graham ${ }^{20}$, Barry Hayden ${ }^{27}$, Edgar Mauricio Hoyos-Padilla, ${ }^{4,28}$, Nigel E. Hussey ${ }^{10}$, Oliver J. D. Jewell29,30, Salvador J. Jorgensen ${ }^{30}$, Alison A. Kock ${ }^{31,32}$, Christopher G. Lowe ${ }^{33}$, Kady Lyons ${ }^{33}$, Lauren Meyer ${ }^{1}$, Gregg Oelofse ${ }^{34}$, Erick C. Oñate-González ${ }^{35}$, Herman Oosthuizen ${ }^{36}$, John B. O'Sullivan ${ }^{30}$, Kristopher Ramm ${ }^{18}$, Gregory Skomali37, Sean Sloan ${ }^{38}$, Malcolm J. Smale ${ }^{39}$, Oscar Sosa-Nishizaki23, Emilio Sperone ${ }^{40}$, Elena Tamburin ${ }^{3,41}$, Alison V. Towner ${ }^{26,42}$, Michelle A. Wcisel ${ }^{43}$, Kevin C. Weng ${ }^{44}$ and Jonathan M. Werry ${ }^{45}$

1 Southern Shark Ecology Group, College of Science and Engineering, Flinders University, Adelaide, SA, Australia, ${ }^{2}$ School of Environment, Science and Engineering, Southern Cross University, Lismore, NSW, Australia, ${ }^{3}$ Instituto Politécnico Nacional, Centro Interdisciplinario de Ciencias Marinas, La Paz, Mexico, ${ }^{4}$ Pelagios Kakunjá A.C., La Paz, Mexico, ${ }^{5}$ CSIRO Oceans and Atmosphere, Hobart, TAS, Australia, ${ }^{6}$ National Marine Science Centre, New South Wales Department of Primary Industries, Coffs Harbour, NSW, Australia, ${ }^{7}$ School of Marine Science and Policy, University of Delaware, Lewes, $D E$, United States, ${ }^{8}$ Hopkins Marine Station, Stanford University, Pacific Grove, CA, United States, ${ }^{9}$ Fish and Wildlife Research Institute, Florida Fish and Wildlife Conservation Commission, St. Petersburg, FL, United States, ${ }^{10}$ Department of Biological Sciences, University of Windsor, Windsor, ON, Canada, ${ }^{11}$ KwaZulu-Natal Sharks Board, Durban, South Africa, ${ }^{12}$ School of Life Sciences, University of KwaZulu-Natal, Durban, South Africa, ${ }^{13}$ National Marine Fisheries Service, Atlantic Highly Migratory Species Management Division, Gloucester, MA, United States, ${ }^{14}$ Department of Ocean Engineering and Marine Sciences, Florida Institute of Technology, Melbourne, FL, United States, ${ }^{15}$ Life History Program, NOAA Southwest Fisheries Science Center, La Jolla, CA, United States, ${ }^{16}$ Department of Development Studies, School of Economics, Development and Tourism, Nelson Mandela Metropolitan University, Port Elizabeth, South Africa, ${ }^{17}$ Marine Conservation Science Institute, Kailua-Kona, HI, United States, ${ }^{18}$ Department of Conservation, Auckland, New Zealand, ${ }^{19}$ Ministry for Primary Industries, Wellington, New Zealand, ${ }^{20}$ National Institute of Water and Atmospheric Research, Wellington, New Zealand, ${ }^{21}$ School of Life Sciences, University of Sussex, Brighton, United Kingdom, ${ }^{22}$ SharkStuff, Poole, Dorset, United Kingdom, ${ }^{23}$ Departamento de Oceanografía Biológica, Centro de Investigación Científica y de Educación Superior de Ensenada, Ensenada, Mexico, ${ }^{24}$ Oceans Research, Mossel Bay, South Africa, ${ }^{25}$ South African Institute for Aquatic Biodiversity, Grahamstown, South Africa, ${ }^{26}$ Department of Ichthyology and Fisheries Science, Rhodes University, Grahamstown, South Africa, ${ }^{27}$ Department for Environment and Water, Adelaide, SA, Australia, ${ }^{28}$ Fins Attached, Colorado Springs, CO, United States, ${ }^{29}$ Centre for Sustainable Aquatic Ecosystems, Murdoch University, Perth, WA, Australia, ${ }^{30}$ Monterey Bay Aquarium, Monterey, CA, United States, ${ }^{31}$ Cape Research Centre, South African National Parks, Cape Town, South Africa, ${ }^{32}$ Institute for Communities and Wildlife in Africa, Department of Biological Sciences, University of Cape Town, Cape Town, South Africa, ${ }^{33}$ Biological Sciences, California State University Long Beach, Long Beach, CA, United States, ${ }^{34}$ Environmental Resource Management, Cape Town, South Africa, ${ }^{35}$ Facultad de Ciencias Biológicas, Universidad Autónoma de Nuevo León, San Nicolás de los Garza, Mexico, ${ }^{36}$ Branch Oceans and Coasts, Department of Environmental Affairs, Cape Town, South Africa, ${ }^{37}$ Massachusetts Division of Marine Fisheries, New Bedford, MA, United States, ${ }^{38}$ Fisheries and Aquaculture Division, Department of Primary Industries and Regions, Adelaide, SA, Australia, ${ }^{39}$ Department of Zoology and Institute for Coastal and Marine Research, Nelson Mandela University, Port Elizabeth, South Africa, ${ }^{40}$ Department of Biology, Ecology and Earth Sciences, University of Calabria, Rende, Italy, ${ }^{41}$ Fundación Alium Pacific, Santiago de Cali, Colombia, ${ }^{42}$ Dyer Island Conservation Trust, Kleinbaai, South Africa, ${ }^{43}$ Michigan State University Museum, East Lansing, MI, United States, ${ }^{44}$ Department of Fisheries Science, Virginia Institute of Marine Science, College of William \& Mary, Gloucester Point, VA, United States, ${ }^{45}$ Griffith Centre for Coastal Management, Griffith University, Gold Coast, QLD, Australia

White sharks, Carcharodon carcharias, are often described as elusive, with little information available due to the logistical difficulties of studying large marine predators that make long-distance migrations across ocean basins. Increased understanding of aggregation patterns, combined with recent advances in technology have, however, 
facilitated a new breadth of studies revealing fresh insights into the biology and ecology of white sharks. Although we may no longer be able to refer to the white shark as a littleknown, elusive species, there remain numerous key questions that warrant investigation and research focus. Although white sharks have separate populations, they seemingly share similar biological and ecological traits across their global distribution. Yet, white shark's behavior and migratory patterns can widely differ, which makes formalizing similarities across its distribution challenging. Prioritization of research questions is important to maximize limited resources because white sharks are naturally low in abundance and play important regulatory roles in the ecosystem. Here, we consulted 43 white shark experts to identify these issues. The questions listed and developed here provide a global road map for future research on white sharks to advance progress toward key goals that are informed by the needs of the research community and resource managers.

Keywords: Carcharodon carcharias, movement, threats, threatened species conservation, TEPS management, wildlife tourism, feeding ecology

\section{INTRODUCTION}

The inherently low abundance and frequent use of pelagic habitats has historically made the white shark (Carcharodon carcharias) difficult to study due to the logistical and financial constraints of regularly accessing individuals. An increased understanding of white shark spatio-temporal distribution has, however, allowed us to identify a number of seasonal aggregations where white sharks can predictably be found. These, along with technological and analytical advances, have facilitated a rising scientific interest in the species and resulted in an increasing number of studies (Figure 1). For example, $\sim 15$ papers per year have been published on white sharks since 2012 compared to three or less per year between 1990 and 2005. This excludes papers from three dedicated symposia, such as the International White Shark Symposium in Hawaii in 2010 (Domeier, 2012b), which greatly increased the number of publications in 1985, 1996, and 2012 when proceedings of these conferences were published. The vulnerable global status of white sharks (Fergusson et al., 2009), their size, high media profile, dramatic interactions with humans, and charismatic nature have also attracted significant public attention.

Aggregation at hot spots spread across the globe has led to different research groups studying the ecology and biology of white sharks, using a broad range of methods and focusing on various research areas. While we can no longer refer to the white shark as a little-known, elusive species, there remain key questions that warrant further investigation and research focus. Here, we take the opportunity of the recent increase in research effort on white sharks to consult with 43 white shark scientists and managers from across the globe, who together have worked on all of the main white shark aggregations and populations (Gubili et al., 2012; Figure 2), to identify key research themes and outstanding questions. The themes developed here provide a global road map for white shark research that will enable further comparisons among aggregation sites and a broader understanding of white shark ecology.

\section{METHODS}

We followed a similar protocol to Hays et al. (2016) in soliciting the expertise of leading white shark scientists and managers. Experts were selected based on their publications and extent of their work on white sharks. They were asked to recommend other individuals from around the world who should also be invited to participate. In addition to these researchers, we also contacted managers from appropriate governmental organizations and attempted to ensure gender and regional balance. The extended list of experts were then each asked to supply up to 10 key research priorities to advance our knowledge of white sharks. Responses were compiled and grouped into 21 research themes. All experts were then asked to vote for their top three research themes. The votes were tallied and a final list of key questions was circulated and agreed upon. In addition to the top research themes, we also collected information about the participant's position (e.g., PhD student, academic), role (e.g., research scientist from a university or governmental organization, manager), number of years working on white sharks, and regional focus (e.g., Australia/New Zealand, Western Atlantic). Each of the top 10 research themes was based on votes from the top three responses and then developed into a specific question, which was expanded to guide future research.

\section{RESULTS AND DISCUSSION}

\section{Overview}

Votes were obtained from 43 respondents, most of them being government employees (33.3\%) and university academics (28.6\%). The remaining respondents were either $\mathrm{PhD}$ students (16.7\%) or post-doctoral fellows (2.4\%). The vast majority of respondents were research scientists $(81.4 \%)$, with only $9.3 \%$ of respondents being managers. There was a strong gender bias toward males (74.4\%). Most of the respondents worked in the eastern Pacific (42.9\%), with a similar representation between 


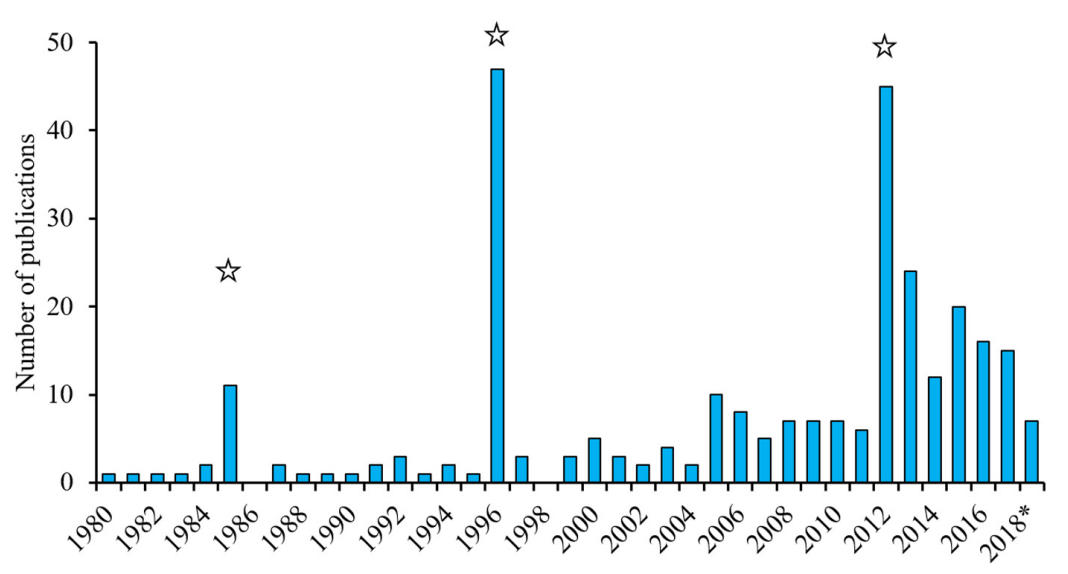

FIGURE 1 | Annual number of white shark publications (1980-2018) based on a Web of Science search (12 June 2018$)$ for items with titles including "white shark(s)" and/or "Carcharodon carcharias". The large numbers of publications in 1985, 1996, and 2012 are due to the publication of books or symposium proceedings about white sharks. * in 2018 indicates that it does not represent a full 12 months.

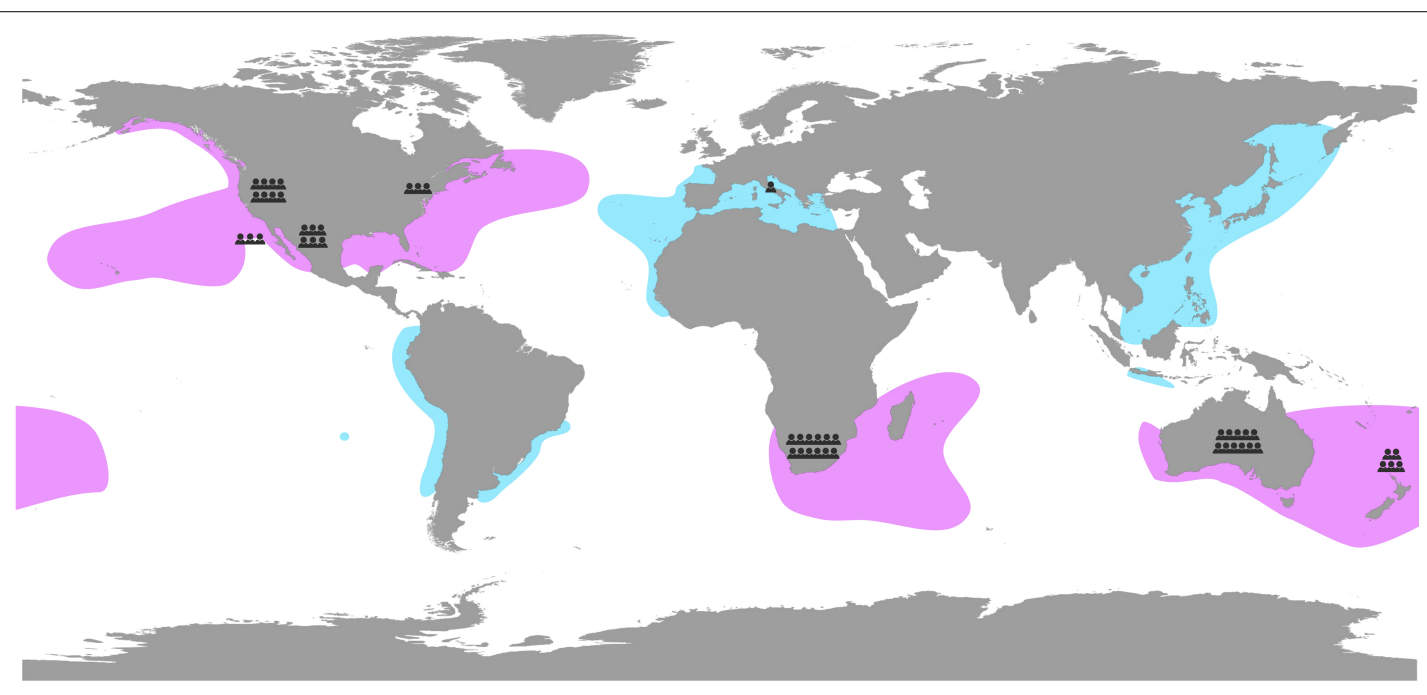

FIGURE 2 | White shark (Carcharodon carcharias) distribution based on known aggregations and tracking data (pink) and confirmed occurrence (blue; also representing lesser-known regions). White shark scientists and managers contributing to this study are represented by small torso located where they have most worked on white sharks.

Australia/New Zealand (28.6\%) and South Africa (23.8\%), and only $4.8 \%$ of respondents working in the Western Atlantic. Respondents had in general worked on white sharks for an extended period, with $60.4 \%$ for $>10$ years and only $7 \%$ for $<5$ years. The resulting top 10 research questions were grouped in three categories: organismal biology, ecology, and socio-economics, management, and conservation, and ranked in descending order of priority within these categories (Figure 3).

\section{Organismal Biology}

\section{What Is the Size and Status of White Shark} Populations?

Assessment of white shark population sizes and trends is necessary for assessing population risk, prioritizing conservation resources, and guiding debates on shark-human conflict and mitigation strategies (Dewar et al., 2013; Dulvy et al., 2014; Braccini et al., 2017). Although white sharks are showing signs of recovery in some regions where the species is wellprotected (e.g., Eastern Pacific, Lowe et al., 2012; Northwest Atlantic, Curtis et al., 2014), most studies have revealed low-tomoderate population sizes (100s-1000s of individuals) (Chapple et al., 2011; Sosa-Nishizaki et al., 2012; Towner et al., 2013; Burgess et al., 2014; Hillary et al., 2018), high relative risk of overexploitation (Chapple and Botsford, 2013; Braccini et al., 2017), and historic declines in abundance (McPherson and Myers, 2009). However, many available abundance estimates remain data-limited (especially across all life-history stages) and have high uncertainty. While some population estimates have been debated, they all suggest relatively naturally low abundance 


\title{
WHITE SHARK RESEARCH PRIORITIES
}

\author{
Organismal biology
}

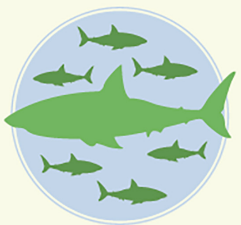

1

What is the size and status of white shark populations?

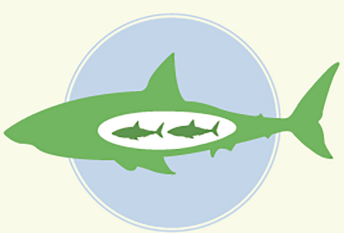

What are the key parameters necessary white sharks?

\section{Ecology}

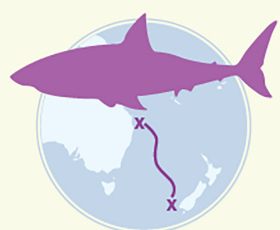

What are the mechanisms (biotic and abiotic) driving the distribution, movements, and migrations of white sharks?

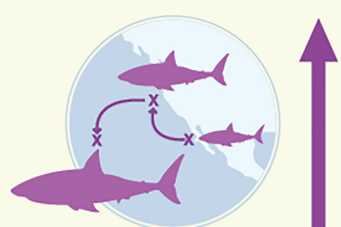

1

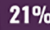

What are the critical habitats of white sharks and how do they change with ontogeny?

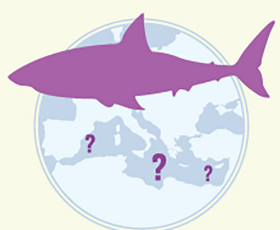

$\Omega$

Where and how frequent are white sharks outside their key known hotspots?

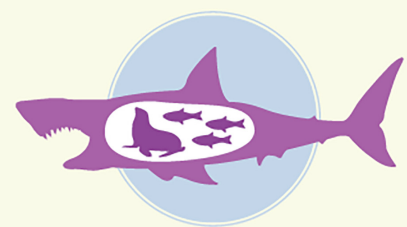

How can we improve our understanding of white shark $14 \%$ diet to infer drivers of movements and habitat preferences, and flexibility in trophic role?

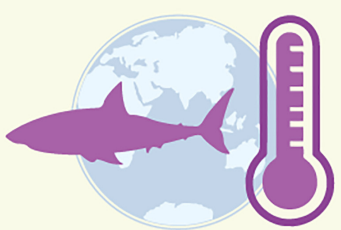

How will climate change impact white

$1 \%$ shark populations?

\section{Socio-economics, management and conservation}

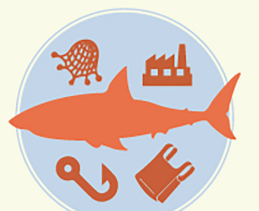

1 $28 \%$
How can we quantify and alleviate current

threats to adequately manage white sharks and ensure their conservation?

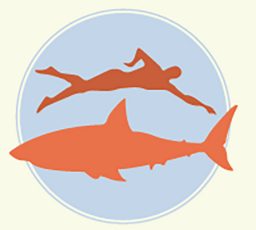

1 $21 \%$
Can we reliably assess and significantly reduce human-shark interactions, and influence public perception of shark bite risks?

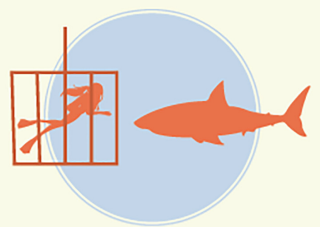

1

$9 \%$ What are the socio-economic benefits and ecological effects of wildlife tourism?

FIGURE 3 | Summary of top 10 research priorities identified by 43 white shark scientists and managers. Priorities are grouped in three categories and ranked in descending order of priority. Number in 'thumbs up' represents the percentage of white shark experts who voted for this research priority. Scientific infographic by David "Ed" Edwards - www.dgedwards.com. 
and highlight the challenges of estimating white shark population size. As a result, abundance data are lacking for understudied populations and reliable abundance trends are missing for most regions. Trends or population indices in white shark populations are much easier to identify than absolute population sizes (e.g., Hewitt et al., 2018); even methods that might be considered unreliable for a true population estimate can provide a trend if they are periodically conducted and compared to historical results from the same method. A better understanding of the demography of white shark populations and estimates of mortality across life-history stages (e.g., Benson et al., 2018) is also needed to reduce uncertainties in modeling outputs (Burgess et al., 2014; Irion et al., 2017). Methods that use an integrated approach combining different methods such as catch statistics from beach protection programs or fisheries bycatch, markrecapture based on photo-identification or electronic tagging, and genetic analysis (e.g., close-kin genetics) are recommended to overcome sampling biases and modeling assumptions (Dewar et al., 2013; Irion et al., 2017; Benson et al., 2018). These methods should be applied across regions and populations to allow for comparisons. Future research should focus on identifying reliable trends in abundance and estimating historical population size from population trajectories so these trends can be assessed and monitored.

\section{What Are the Key Parameters Necessary to Quantify the Reproductive Output of White Sharks?}

Our understanding of the reproductive strategies and dynamics of white sharks is poor. Mature near-term females are infrequently encountered and rarely sampled, leading to a relative dearth of information about their reproductive cycle, although genetic studies have given some insight into the use of behaviors like philopatry and multiple paternity by female white sharks (Pardini et al., 2001; Jorgensen et al., 2009; Fitzpatrick et al., 2012). As in other lamnid sharks, white shark embryos are nourished by large numbers of small nutritive eggs (Francis, 1996; Saídi et al., 2005; Christiansen et al., 2014). However, a recent study showed that early-term embryos may also rely heavily on lipid histotrophy, in which oil-rich "milk" is secreted by the uterus lining (Sato et al., 2016); this recent discovery is unique among sharks, and emphasizes our limited knowledge of the white shark's reproductive strategy. Similarly, we have only rough estimates of litter size (average 5-10, range 2-17) and gestation period (almost certainly longer than 1 year and perhaps as long as 20 months) (Francis, 1996; Christiansen et al., 2014). The duration of the reproductive cycle is unknown, with longterm satellite and acoustic tracking, and photo-identification studies from the Northwest Pacific suggesting either a 2year or unpredictable cycle (Dewar et al., 2013; Domeier and Nasby-Lucas, 2013; Chapple et al., 2016). Although reproductive parameter estimates and priors are available for use in population models (Dewar et al., 2013; Dillingham et al., 2016; Hillary et al., 2018), the high degree of uncertainty in these inputs greatly weakens estimates of reproductive output and population growth rate (e.g., $\left.r_{\max }\right)$. Importantly, it is unknown whether fecundity increases with maternal size (as it does in some other shark species), which invariably means modelers assume that it does not. The most pressing reproductive research requirement is the development of more precise and accurate estimates of age-at-maturity, and annual, age-specific pup production per adult female. Current estimates of the size and age of maturity are based on unacceptably low sample sizes. Novel, non-lethal methods to determine reproductive parameters of sharks are now available, e.g., endocrine assessment (Awruch et al., 2008) and ultrasonography (Sulikowski et al., 2016), and should be used during standard tagging procedures when logistically possible.

\section{Ecology}

What Are the Mechanisms (Biotic and Abiotic) Driving the Distribution, Movements, and Migrations of White Sharks?

An assessment of the movement and migrations of white sharks using various tracking technologies has arguably been the dominant focus of white shark research. In general, when and where white sharks occur and migrate are well-described for most populations (e.g., Jorgensen et al., 2009; Domeier, 2012b; Duffy et al., 2012). White sharks exhibit periodic latitudinal (or longitudinal in southern Australia) movements, broadly occupying sea surface temperatures ranging $5-30^{\circ} \mathrm{C}$ during their coastal distribution (Bruce et al., 2006; Weng et al., 2007a; Francis et al., 2012; Dicken and Booth, 2013; Domeier and Nasby-Lucas, 2013; Curtis et al., 2014; Skomal et al., 2017). However, the seasonal patterns and the ecological and environmental drivers of the distribution of white sharks across regions are still not completely understood. Future research should focus on the causal mechanisms driving patterns of white shark coastal and offshore distribution (e.g., seasonality, carrying capacity, sexual, and size segregation), a better understanding of factors affecting white shark distribution away from pinniped colonies and productive temperate coastal ecosystems into what can be areas of comparatively low biological productivity (e.g., for reproduction or parturition, thermoregulation, prey availability, or predator avoidance, e.g., orca), and their implications for conservation and management. Interpretation of existing data and future work can be best framed within three distinct stages of white shark ontogeny: (1) early life movements and the location of nurseries, which are largely defined by prey availability (Dewar et al., 2004) and ambient temperature (White, 2016) due to endothermic requirements of neonates and small juveniles (Carlson et al., 2004); (2) the juvenile to subadult stage, where ontogenetic shifts in diet, morphology, and habitat occur (Domeier, 2012a; Skomal et al., 2017); and (3) the adult stage, where reproduction and resource acquisition become important drivers of distribution (Jorgensen et al., 2009; Domeier and Nasby-Lucas, 2013; Kock et al., 2013). Comparative global studies using existing data in combination with new physiological investigations measuring body and external temperatures hold promise for increasing our understanding of the mechanisms driving distribution and movements, and directing future studies.

\section{What Are the Critical Habitats of White Sharks and How Do They Change With Ontogeny?}

Although the legal definition of critical habitat differs by country, as does the extent to which this habitat is protected, it generally 
comprises areas that provide the most favorable habitats for a species to feed, mature, and reproduce throughout its life cycle (Valavanis et al., 2008). Much of what we know about white shark habitat comes from fisheries-dependent catch records and tracking studies, but the extent to which these critical areas provide optimal habitat for feeding, growth, and reproduction remains largely unknown. Oceanic movements, anomaly events like the Blob (Gaxiola-Castro et al., 2015; Peterson et al., 2015) and large-scale climatic variability, e.g., linked to the El NiñoSouthern Oscillation, further complicate the process as these sharks move vertically and horizontally through highly diverse habitats (Bruce and Bradford, 2012; Francis et al., 2012; Jorgensen et al., 2012; White, 2016; Skomal et al., 2017). Numerous statistical approaches have been devised in recent years to model critical habitat based on environmental and presence-absence data sets (Valavanis et al., 2008), but this still needs to be done for many subpopulations of white sharks, and across all lifehistory stages. While the majority of published studies are on subadult and adult stages, some knowledge exists for juvenile and young-of-the-year stages (Dewar et al., 2004; Weng et al., 2007b; Bruce and Bradford, 2012; Lyons et al., 2013; White, 2016; Oñate-González et al., 2017; Curtis et al., 2018). Owing to the direct relationship between stock size and recruitment for sharks (Holden, 1974; Hoenig et al., 1990), it is imperative that new studies are implemented to better understand the preferred habitats frequented by juvenile sharks. In addition, movement studies using new and innovative technologies that correlate habitat use with direct and indirect observations of behavior (e.g., Whitney et al., 2010; Skomal et al., 2015; White, 2016) are needed for each life history stage for each population. This can be combined with environmental and prey availability data collected in situ and/or remotely so as to model that habitat and define its functional role. Determining the habitat preferences and the consequent critical habitats for the different life stages will be crucial for effective conservation and management practices now and in the future.

\section{Where and How Frequent Are White Sharks Outside Their Key Known Hotspots?}

While white sharks have been extensively studied at key aggregation sites throughout the world, other areas within their distribution are little studied (e.g., South America, seamounts, deep-sea canyons). In those regions, systematic documentation of sightings and catches, and biological sampling of landed sharks where possible, remain a priority. Emphasis should be placed on the identification of additional aggregation sites because these areas facilitate research, particularly satellite tagging, and protection, if needed (Christiansen et al., 2014). For example, in the Mediterranean, where a relatively large amount of historic and contemporary distribution records have been documented (e.g., Fergusson et al., 2000; Sperone et al., 2012b; Kabasakal, 2014), the development of habitat suitability models could accelerate this process, test hypotheses about the extent of putative nursery areas, ontogenetic and seasonal habitat shifts, and predator-prey associations (Fergusson, 1996, 2002; Soldo and Jardas, 2002; Morey et al., 2003; Soldo and Dulčić, 2005), as well as inform regional conservation initiatives (e.g., de Juan and Lleonart, 2010). New molecular tools such as environmental DNA (eDNA) sequencing, which uses filtered water samples to noninvasively identify species from trace DNA, can contribute toward understanding movement patterns of large migratory marine fauna such as sharks and cetaceans at species and community level (Larson et al., 2017; Bakker et al., 2017; Baker et al., 2018), and pinpointing habitat use by endangered sawfishes (Simpfendorfer et al., 2016). For instance, although white sharks appear to be exceptionally rare in South American waters, archeological and historical evidence suggest resident populations may have been extirpated by intense fishing (Cione and Barla, 2008; Amorim et al., 2017). Fisher interviews, aerial surveys, and eDNA surveys around pinniped colonies could be used to determine if white sharks persist in areas in South America where they were previously documented as well as other areas.

\section{How Can We Improve Our Understanding of White Shark Diet to Infer Drivers of Movements and Habitat Preferences, and Flexibility in Trophic Role?}

White sharks are considered generalist predators feeding on diverse prey items (Cliff et al., 1989), with a marked ontogenetic shift in diet and feeding behavior (Estrada et al., 2006; Hussey et al., 2012). As such, it is imperative that we improve information about the trophic ecology of white sharks across different lifestages, sex, and across their distribution (including offshore areas and poorly known populations) as it informs our understanding of habitat shifts and movements. Our understanding of the effects of sex and size on inter-individual variation in diet has yet to be fully explored (but see Kim et al., 2012; French et al., 2017, 2018), and may reveal complex ecotypes similar to that observed for higher order mammals such as orca (Orcinus orca; Ford et al., 1998). Understanding of the ecological role of white sharks over varying spatio-temporal scales is limited, such that regional and inter-ocean comparisons of the trophic ecology of white shark populations are needed to promote a holistic understanding of this top predator's role in our global oceans. For example, it has been demonstrated that mature female white sharks in the Eastern Pacific spend the majority of their time in offshore waters that are devoid of small marine mammals (Domeier and Nasby-Lucas, 2013), indicating that our understanding of the adult diet is poorly known. The potential for white sharks to exhibit complex population feeding behaviors and exert nonlethal influences (De Vos et al., 2015a,b; Hammerschlag et al., 2017) would have consequences for accurately characterizing their role in terms of top-down ecosystem control, to quantify nutrient routing and total nutrient transfer, and may require a reconsideration of management to account for population subunits. Elucidating the trophic ecology of white sharks calls for the enhanced use of established (i.e., gut content and stable isotopes) and emerging (i.e., fatty acids, trace elements, eDNA, food-web models) toolsets. Quantification of biochemical tracer (including fatty acids and stable isotopes) turnover rates of different tissues (e.g., blood, muscle, sub-dermal layer), mapping of baseline isotopic signatures, and isotopic and fatty acid data from potential prey across white shark distributions are needed to improve our understanding of diet variations and 
prey selection, and link these to movements and habitat use across populations. Furthermore, combining data from various ecological tracers including established (nitrogen and carbon) and less commonly used isotopes (oxygen and hydrogen in Vennemann et al., 2001), cutting edge ecological tracers such as amino-acid compound-specific isotope analysis (AA-CSIA), fatty acids (Pethybridge et al., 2014; Meyer et al., 2017), and trace elements (Mull et al., 2012) will complement these data streams and generate novel insights into white shark trophic roles (Hussey et al., 2015; Munroe et al., 2018). For example, integrating stable isotope profiles derived from vertebrae (Kim et al., 2012; Christiansen et al., 2015) with contaminant profiles at the point of capture (Lyons et al., 2013; Beaudry et al., 2015; McKinney et al., 2016) or sampling consecutive teeth from jaws held in private collections/museums (Polo-Silva et al., 2012) can be used to reveal ontogenetic shifts in an individual white shark's trophic ecology. Concomitantly, retrospective analyses of archived samples will permit reconstruction of historic baselines and an understanding of how white shark populations are changing and adapting to human impacts in our oceans. The integration of localized and ocean basin movement data with tracer data in time clock mixing models (accounting for size and growth, tissue turnover, and movement rates of animals; Carlisle et al., 2012; Heady and Moore, 2013) presents an additional approach to examining habitat use and diet preferences. Food web modeling exercises, that integrate the various data streams detailed above, have yet to be used to predict the consequences of alternating white shark population trends (i.e., decrease as a result of exploitation versus increase from successful protection). Approaches such as Ecopath, ecosim, and ecospace will address shifting predator demographic trends and assess how those shifts shape and impact overall ecosystems (Pauly et al., 2000; Kitchell et al., 2002).

\section{How Will Climate Change Impact White Shark Populations?}

White sharks are highly mobile across shelf and oceanic environments and have a very broad temperature tolerance (5$30^{\circ} \mathrm{C}$; Weng et al., 2007a; Francis et al., 2012; Skomal et al., 2017), suggesting that their populations are less vulnerable to direct effects of climate change compared to other species (Chin et al., 2010; Hazen et al., 2012). However, juveniles using coastal nurseries in shallow waters will likely be more exposed to and affected by climate change. Additional research is warranted using existing habitat relationships to model future distribution under various climate change scenarios (Hazen et al., 2012), including shifts in migratory range, phenology, and poleward shifts, or contraction of critical habitat areas (e.g., foraging grounds, nursery areas) (Koehn et al., 2011; Pecl et al., 2017). With temperatures rising and oxygen levels falling in the global ocean, it is essential to understand the physiological limits of key species, which can be determined experimentally (Del Raye and Weng, 2015). While the physiological performance of white sharks under future climate conditions has not yet been directly assessed experimentally, and such experiments may not be possible with large bodied species, respirometry methods have been developed to test these questions (Payne et al., 2015). Other approaches to assess physiological responses to environmental perturbations do not require holding animals captive in experimental facilities, such as enzyme analysis (Dickson et al., 1993) and gene expression (Somero, 2010). Indirect effects through climate-driven disruptions of ecosystem and food web dynamics could be more significant for sharks, including the possibility of spatio-temporal shifts in the availability of prey resources (Chin et al., 2010; Koehn et al., 2011; Pecl et al., 2017). Climate-related shifts in anthropogenic activities, specifically fisheries, are also an emerging concern as they relate to potential changes in bycatch susceptibility in the open ocean, and the vulnerability of nursery habitat in shallow coastal embayments (Bangley et al., 2018). Investigating these complex dynamics under current and future environmental conditions is crucial in the face of climate change, but likely to be challenging, requiring concerted multidisciplinary approaches (e.g., stable isotopes analysis, prey monitoring, and telemetry, together with genetic diversity analysis and fishery-dependent monitoring).

\section{Socio-Economics, Management, and Conservation \\ How Can We Quantify and Alleviate Current Threats to Adequately Manage White Sharks and Ensure Their Conservation?}

Key threats for white sharks are known but quantification of the effects of these threats, and their mitigation and prevention, remains important concerns. Regulations to protect white sharks were established for many populations (e.g., Australia, South Africa, United States, Mexico, and New Zealand) 10-25 years ago, based on vulnerability to overexploitation (Compagno, 1991). Yet, white sharks are still taken within protected regions and frequently swim across jurisdictional boundaries, complicating management and requiring the consideration for cross-jurisdictional regulations (Harrison et al., 2018). White sharks also venture into offshore international waters where they remain unprotected, where the sources and extent of bycatch and fishing-related mortality are largely unknown and may vary across life-history stages. Shallow, warm-temperate coastal nursery areas are sometimes protected, but young-of-the-year and juveniles may still be vulnerable as bycatch to various fisheries including drift and bottom-set gillnetting, seine-netting, trawling, longlining, and recreational angling (e.g., Lowe et al., 2012; Santana-Morales et al., 2012; Lyons et al., 2013; Ramirez-Amaro et al., 2013; Curtis et al., 2014; Oñate-González et al., 2017). Quantifying commercial and sport bycatch (Lowe et al., 2012), and mortality (Benson et al., 2018), as well as post-release survival (Lyons et al., 2013), and obtaining a better understanding of fisheries practices and locations are necessary to determine whether existing conservation strategies are effective for each country. The ability to overlay tracking data with threats (e.g., commercial fishing activity, seismic surveys, oil, and gas leases) (e.g., Lyons et al., 2013; Queiroz et al., 2016) provides an opportunity to better identify sources of potential mortality or locations where white sharks might be most exposed to cumulative threats. The impact of any new fisheries overlapping with white shark distribution and migration routes 
should also be evaluated. Semi-quantitative risk assessments and other data-poor approaches (e.g., Robbins et al., 2017) can then be used to identify and synthesize key threats and give management a basis to direct future monitoring and threat mitigation efforts (e.g., reducing net soak-time; Lyons et al., 2013) in the most sensitive regions. The need to understand the efficacy of conservation strategies also raises questions about the spatial scale at which populations can and should be managed. Although they are one of the few reliably quantified and monitored sources of mortality (e.g., Reid et al., 2011), existing and new shark control programs pose additional challenges to white shark conservation strategies. Many indirect threats such as long-term exposure to pollutants and disturbance through expanding maritime activity (e.g., seismic exploration, mineral, and oil extraction) have been poorly studied. This is particularly important because, as top predators, white sharks are likely to be exposed to high levels of heavy metals and organic pollutants, although the impact on their health and fecundity, and longevity is undetermined (Mull et al., 2012, 2013). Comparisons among populations could be used to test predictions of changing behavior or alterations in population dynamics in response to these threats. Elucidating and mitigating threats continue to be a major challenge to conservation and management.

\section{Can We Reliably Assess and Significantly Reduce Human-Shark Interactions, and Influence Public Perception of Shark Bite Risks?}

Although the global number of white shark bites remains low, localized increases in such incidents as well as interactions have led to growing pressure from the general public for governments to initiate policies that can negatively affect white shark populations (Burgess and Callahan, 1996; Curtis et al., 2012; Kock et al., 2012; Meeuwig and Ferreira, 2014). For example, culling or targeted killing of large sharks considered to be an imminent threat have been used as a response to shark bites (e.g., in Egypt, La Reunion Island, Australia), but has not been demonstrated to significantly reduce risk of shark bites (e.g., Wetherbee et al., 1994; Holland et al., 1999). Public expectations of being safe from sharks when undertaking marine activities require a better understanding of human-shark interactions, effectiveness of current mitigation measures, and improved public education outreach. Long-term databases (e.g., International Shark Attack File; Shark Spotters) provide an opportunity to delve further into patterns in shark bites and human-shark spatio-temporal overlap for management of human-shark interactions (Engelbrecht et al., 2017). This could lead to improved ability to predict shark occurrence and the likelihood of a shark bite (Ferretti et al., 2015). For example, a better understanding of the impact of rising sea temperatures could be used for pre-emptive management and education to reduce or mitigate shark-human interaction risk in areas at higher latitudes (Payne et al., 2018). The quick succession of shark bites occurring in multiple locations has led to the development and use of various shark bite mitigation measures (e.g., personal deterrents; surveillance/realtime monitoring), many of which still need to be assessed. Although a few devices have recently been tested (e.g., Huveneers et al., 2013b, 2018b; Kempster et al., 2016; O'Connell et al., 2018), there is a need for transparency and standardization of protocols and variables used to test the effectiveness of personal and arearelated deterrents. Ensuring such consistency will enable direct comparisons of products and mitigation measures. Although trends in the number of shark bites are not necessarily correlated to white shark abundance (Kock and Johnson, 2006; Ferretti et al., 2015), recovery of white shark populations can lead to increased number of sightings, media events, and human-shark interactions (Skomal et al., 2012; Curtis et al., 2014). This could potentially result in public pressure to downgrade or remove legislated protection or to initiate targeted culls (Ferretti et al., 2015). The emotional response of the public to human-shark interactions (Crossley et al., 2014) and negative media portrayal (Muter et al., 2013; Sabatier and Huveneers, 2018) requires scientists and managers to rethink how to reconcile public safety in a proactive manner with the recovery of populations and increase the capacity for education to change public perception (Pepin-Neff and Wynter, 2018).

\section{What Are the Socio-Economic Benefits and Ecological Effects of Wildlife Tourism?}

Five countries currently conduct white shark-focused tourism activities: Australia, South Africa, United States, Mexico, and New Zealand (Bruce, 2015). The cage-diving industry is part of the US\$314 million generated annually by shark-related wildlife tourism (Cisneros-Montemayor et al., 2013), but what part is not clear. Economic evaluation of white shark tourism industries has only taken place in a few regions (e.g., Gansbaai, South Africa, Hara et al., 2003; Neptune Islands, Australia, Huveneers et al., 2017); evaluation at other cage-diving sites would enable a quantitative comparison in the regional importance of these industries, thereby providing a global estimate of the value of white shark cage-diving. White shark tourism also offers an opportunity to foster participant awareness and engender proconservation attitudes through education and meaningful firsthand experiences of white sharks (Apps et al., 2018; Chivell, 2018). However, the conservation benefits of white shark tourism and associated interpretative programs to enhance learning of participants and promote conservation remain unclear due to limited empirical evidence of the educational benefits of the cage-diving industry. From an ecology perspective, some of the effects from tourism have been investigated in South Africa and Australia where changes in behavior, residency, activity, and space use were noted (Laroche et al., 2007; Sperone et al., 2012a; Bruce and Bradford, 2013; Huveneers et al., 2013a, 2018a; Towner et al., 2016). Whether these changes affect energetic budget (e.g., Huveneers et al., 2018a) or are detrimental to individuals or populations is mostly unknown, and has been identified as a priority requiring further investigation (Brena et al., 2015; Gallagher and Huveneers, 2018). The scarcity of easily accessible white shark aggregations without associated tourism has made it difficult to assess the effects of wildlife tourism due to the lack of control sites. Aggregation sites where tourism activities do not take place provide an opportunity to compare white sharks at impacted vs. control sites and should be used to investigate the impacts of the tourism industry. The public has also raised concerns about the potential increased threat to human safety 


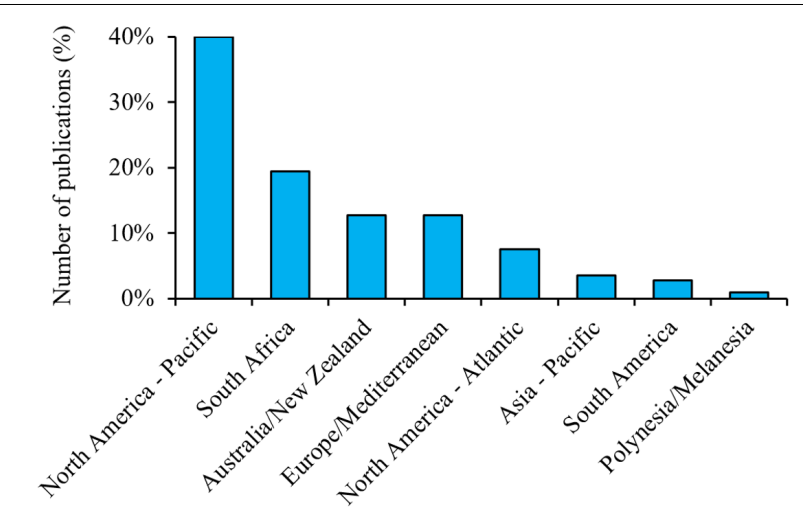

FIGURE 4 | Number of publications (all years) about white sharks per region based on a Web of Science search (12 June 2018) for items with titles including "white shark(s)" and/or "Carcharodon carcharias." $N=422$.

due to the perception that white sharks are making associations between food and humans as a result of these tourism operations, and that such association increases shark bite risk. There are, however, no easy scientific ways to unequivocally investigate this idea because of the inherently low number of white shark attacks, which renders any statistical analyses difficult. Such associations or learnt behavior might not only occur because of shark tourism, but could also take place due to other activities such as commercial fishing or aquaculture. A better understanding of shark learning and associative capabilities would enable scientists to address some of these concerns and gain the necessary information to regulate the tourism industry if required. The behavioral effects of white shark tourism can also extend beyond the focal species (Rizzari et al., 2017), and understanding the effects of these activities on other species occurring at tourism sites is an important consideration for management regimes that aim to minimize anthropogenic ecosystem changes due to tourism.

\section{ADDITIONAL COMMENTS}

\section{Other Mentioned Research Priorities}

While the prioritization process identified 10 priority research questions, the expert group listed a total of 21 research themes. The 11 themes that were not identified as a priority were varied and ranged from basic life history (determination of growth rate, age-at-maturity, and longevity across the different populations) to social science (exploration of current public perceptions and media, incl. mass media, social media, documentaries, portrayal of white sharks, and the relationship between those and governmental responses and policies). Other research themes related to biology or ecology of white sharks included sensory biology and learning (hearing, visual acuity, and general sensory biology of white sharks in relation to their behavior, learning capabilities, and memory retention of white sharks), physiology (how important are different sources of heat production and retention, e.g., swimming, digestion, retia, and how do they contribute to thermal balance and endothermic capacity, how will performance be affected by climate change), contaminant exposure (levels of pollutants, e.g., microplastics, heavy metals, organic contaminants, and their effects on white shark health, reproduction, endocrine and immune systems, and potential offloading to neonates), energetics (estimation of basic metabolic rates and energetic requirements, and their variation through ontogeny and during migrations, to what extent does foraging on pinnipeds or marine mammals fuel white shark energy stores and migrations), social interactions (social component to white shark aggregations), and stock structure (contemporary connectivity between populations within and between ocean basins, and barriers to mixing, historical relationships between contemporary populations, degree of relatedness of white sharks within aggregations, i.e., siblings, parent-offspring pair). The value of white sharks in terms of ecosystem service (humanrelated, e.g., tourism, fisheries enhancement, and ecologyrelated, e.g., prey control, nutrient reallocation), and education and awareness (role of scientists, government, non-profit organizations, citizen science, and wildlife tourism in educating the general public and improving knowledge and understanding of white shark ecology and conservation status) were also mentioned as research themes. While most research themes identified by the experts were related to either ecology or socioeconomic matters, experts also cited scientific methods and ethics as an important theme (e.g., need to minimize tag size and impacts, and improve training; creation of an international sample and data depository to avoid duplication and maximize information sharing). Although none of these 11 research themes ranked in the top 10, their initial identification at the start of the prioritization process suggests that they should also be considered relevant future research directions.

\section{Managers' Priorities}

Although only $~ 9 \%$ of respondents were managers, a comparison of their responses with those of research scientists confirms that both groups agree on research priorities for white sharks. Six of the seven research themes listed in the top three by managers were also in the overall expert group's top 10. The top three research themes for the expert group (abundance and trends; movements and migrations; and threats, conservation, and management) were also listed in the managers' research priorities, showing a high level of agreement between managers and research scientists. Only one of the managers' top three was not included in the overall expert group top 10, namely public perception and media portrayal, suggesting that this theme might be important to managers, but not research scientists. As managers are often required to balance societal expectations with conflicting scientific advice on the species' conservation status and behavior they may be more interested in research that allows them to anticipate stakeholder and/or public concerns, understand the nature and drivers of these, and identify effective ways of addressing these concerns and influencing public opinion. The identification of this research theme by managers suggests a gap where new expertise is required to fulfil the managers' need for further research. While we engaged with managers during this prioritization process, 
and many people within the research scientist group work closely with managers, the low representation of managers suggests potentially problematic disconnects between scientists and professionals in resource management.

\section{Geographic Bias}

Although the geographical bias in respondents was minimized by ensuring that relevant experts from all regions were invited to contribute, there were still differences between regions, with a small number of respondents being from the Northwest Atlantic. Such bias is evident in the current research effort in terms of peer-reviewed publications (Figure 4). The Northeast Pacific region had more than twice as many publications as the second region (South Africa), which was a larger bias than seen among our respondents. This overall geographic bias likely relates to the location of known subadult and adult aggregation sites and nursery areas, accessibility of aggregations (e.g., close distance from mainland), and the length of time that they have been studied (e.g., over 30 years for some central California sites), but also correlates to places where cage-diving tourism takes place. These industries can provide invaluable information about the spatio-temporal changes in white shark abundance and an opportunity to maximize research effort during periods of high white shark presence (Ward-Paige, 2014). Cage-diving companies can provide logistic support and platforms for scientists to collect data. However, tourism activities can also alienate other stakeholders (e.g., commercial fishers, recreational water users), diminishing co-operation with scientists by those groups (C. Duffy; personal communication). The logistical ease and financial incentive of working in some of these locations have led to a dearth of information from other lesser-known areas (Figure 4). Funding opportunity and currency strength can also be a limiting factor in the ability to undertake research in developing countries.

\section{Novel Tools and Techniques}

The development of novel technological and analytical tools continues to enhance the capabilities of researchers studying white sharks and other marine megafauna, especially in the areas of telemetry and genetic analysis. A large portion of tagging studies on white sharks relate to movements and migrations made possible through the continued technological developments of acoustic and satellite tags in the last 10 years in particular (Bruce et al., 2005; Weng et al., 2007a; Jorgensen et al., 2009; Bonfil et al., 2010; Domeier and Nasby-Lucas, 2013). More recently, biologging devices have further expanded this by incorporating sensors (e.g., accelerometers, animal-born cameras) which enable investigators to go beyond "where and when" and into "why or how." Such technological advancements can expand our ability to study white sharks by accounting for activity or bioenergy expenditure [see Cooke et al. (2016a) for a review on fish], and documenting white shark behavior via four-dimensional movements in real time and cameras (Chapple et al., 2015; Jorgensen et al., 2015; Whitney et al., 2016). The ability to incorporate various sensors into tags also contributes toward better understanding basic life history data (e.g., reproductive parameters), which remain poorly understood. Recent advances in DNA-based techniques, such as eDNA mentioned above, as well as the decreasing cost and increasing accessibility of molecular methods, have also provided new ways to approach white shark research and management (Gubili et al., 2012; Larson et al., 2017). Speciesspecific tools such as next-generation genome sequencing data have shed light on such varied aspects of white shark biology as reproductive behavior, critical habitat use, regional biodiversity, and estimating effective population size (e.g., O'Leary et al., 2013, 2015; Oñate-González et al., 2015; Hillary et al., 2018). In the near future, a fully sequenced and annotated white shark reference nuclear genome will likely enable the development of even more sophisticated tools for examining white shark ecology and evolution. Such important baseline information, including population-specific variables like genetic diversity, connectivity, and growth rates, is critical to reliably understand white shark population dynamics and monitor recovery.

\section{Ethics Statement}

Experts also cited scientific methods and ethics as an important research theme, recognizing the need to develop minimally invasive and adaptable tools to investigate white shark biology and ecology, and to study the effect of research (e.g., tagging) on stress levels, migratory behavior, and individual or population fitness (i.e., Jewell et al., 2011; Hammerschlag et al., 2014). Although this issue was not in the top 10 research priorities, it shows that scientists are considering the welfare and ethics of studying this threatened species. It also emphasizes the ethical responsibility of collecting the maximum information and biological samples from dead white sharks such as obtained through targeted killing, beach protection programs, or fisheries bycatch. Such information and samples should be made readily available to researchers and easily accessible through online depositories like Otlet ${ }^{1}$. The inclusion of ethical considerations as a research priority shows the motivation to continue improving scientific methods and tools, which has become increasingly important as failure to do so can create conflict and undermine the scientific data collected and ensuing management decisions (Cooke et al., 2016b).

\section{CONCLUSION}

Our aim was to present the top 10 research questions that should be considered when developing research programs about white sharks. We do not claim that this list of questions is exhaustive and that other research topics are not valuable and should not be undertaken, but we believe that our list captures the most important research priorities and key issues. At a minimum, we hope that this article will lead to researchers thinking about the various questions we have identified, about ways to answer them, encourage greater collaborations, and that the questions

\footnotetext{
${ }^{1}$ https://otlet.io/
} 
and themes described in this article will provide a roadmap for future research on white sharks that will accelerate progress.

\section{AUTHOR CONTRIBUTIONS}

$\mathrm{CH}$ conceived and wrote the manuscript. AK, CD, CL, EO-G, GC, GS, LM, MF, EMH-P, NH, OS-N, SJ, and TC co-wrote the manuscript. KL produced Figure 1. TC did the literature review and produced Figures 2, 4. All authors responded to the survey and edited draft versions of the manuscript.

\section{REFERENCES}

Amorim, A. F., Arfelli, C. A., Bornatowski, H., and Hussey, N. E. (2017). Rare giants? A large female great white shark caught in Brazilian waters. Mar. Biodivers. 48, 1687-1692. doi: 10.1007/s12526-017-0656-9

Apps, K., Dimmock, K., and Huveneers, C. (2018). Turning wildlife experiences into conservation action: can white shark cage-dive tourism influence conservation behaviour? Mar. Policy 88, 108-115. doi: 10.1016/j.marpol.2017. 11.024

Awruch, C. A., Pankhurst, N. W., Frusher, S. D., and Stevens, J. D. (2008) Endocrine and morphological correlates of reproduction in the draughtboard shark Cephaloscyllium laticeps (Elasmobranchii: Scyliorhinidae). J. Exp. Zool. A Ecol. Genet. Physiol. 309, 184-197. doi: 10.1002/jez.445

Baker, C. S., Steel, D., Nieukirk, S., and Klinck, H. (2018). Environmental DNA (eDNA) from the wake of the whales: droplet digital PCR for detection and species identification. Front. Mar. Sci. 5:133. doi: 10.3389/fmars.2018. 00133

Bakker, J., Wangensteen, O. S., Chapman, D. D., Boussarie, G., Buddo, D., Guttridge, T. L., et al. (2017). Environmental DNA reveals tropical shark diversity in contrasting levels of anthropogenic impact. Sci. Rep. 8:16886. doi: 10.1038/s41598-017-17150-2

Bangley, C. W., Paramore, L., Shiffman, D. S., and Rulifson, R. A. (2018). Increased abundance and nursery habitat use of the bull shark (Carcharhinus leucas) in response to a changing environment in a warm-temperate estuary. Sci. Rep. 8:6018. doi: 10.1038/s41598-018-24510-z

Beaudry, M. C., Hussey, N. E., McMeans, B. C., McLeod, A. M., Wintner, S. P., Cliff, G., et al. (2015). Comparative organochlorine accumulation in two ecologically similar shark species (Carcharodon carcharias and Carcharhinus obscurus) with divergent uptake based on different life history. Environ. Toxicol. Chem. 34, 2051-2060. doi: 10.1002/etc.3029

Benson, J. F., Jorgensen, S. J., O'Sullivan, J. B., Winkler, C., White, C. F., GarciaRodriguez, E., et al. (2018). Juvenile survival, competing risks, and spatial variation in mortality risk of a marine apex predator. J. Appl. Ecol. 55, 28882897. doi: 10.1111/1365-2664.13158

Bonfil, R., Francis, M. P., Duffy, C., Manning, M. J., and O’Brien, S. (2010). Largescale tropical movements and diving behavior of white sharks Carcharodon carcharias tagged off New Zealand. Aquat. Biol. 8, 115-123. doi: 10.3354/ ab00217

Braccini, M., Taylor, S., Bruce, B., and McAuley, R. (2017). Modelling the population trajectory of West Australian white sharks. Ecol. Modell. 360, 363377. doi: 10.1016/j.ecolmodel.2017.07.024

Brena, P. F., Mourier, J., Planes, S., and Clua, E. (2015). Shark and ray provisioning: functional insights into behavioral, ecological and physiological responses across multiple scales. Mar. Ecol. Prog. Ser. 538, 273-283. doi: 10.3354/ meps11492

Bruce, B. D. (2015). A Review of Cage-Diving Impacts on White Shark Behaviour and Recommendations for Research and the Industry's Management in New Zealand. Hobart: Department of Conservation.

Bruce, B. D., and Bradford, R. W. (2012). "Spatial dynamics and habitat preferences of juvenile white sharks in eastern Australia," in Global Perspectives on the Biology and Life History of the White Shark, ed. M. L. Domeier (Boca Raton, FL: CRC Press), 225-270. doi: 10.1201/b11532-20

\section{ACKNOWLEDGMENTS}

We thank the editors for inviting us to submit this manuscript and the many funding agencies and tourism industries which supported the research to date, enabling the collection of essential data to advance our understanding of white shark ecology and biology. Rory McAuley, Russ Bradford, and Ashley Leedman are thanked for their contribution to this paper. We also thank David "Ed" Edwards (www. dgedwards.com) for providing the scientific infographic used as Figure 3.

Bruce, B. D., and Bradford, R. W. (2013). The effects of shark cage-diving operations on the behaviour and movements of white sharks, Carcharodon carcharias, at the Neptune Islands, South Australia. Mar. Biol. 160, 889-907. doi: 10.1007/s00227-012-2142-z

Bruce, B. D., Stevens, J. D., and Bradford, R. W. (2005). Site Fidelity, Residence Times and Home Range Patterns of White Sharks Around Pinniped Colonies. Hobart: Australian Government Department of Environment and Heritage.

Bruce, B. D., Stevens, J. D., and Malcolm, H. (2006). Movements and swimming behaviour of white sharks (Carcharodon carcharias) in Australian waters. Mar. Biol. 150, 161-172. doi: 10.1007/s00227-006-0325-1

Burgess, G. H., Bruce, B. D., Cailliet, G. M., Goldman, K. J., Grubbs, R. D., Lowe, C. G., et al. (2014). A re-evaluation of the size of the white shark (Carcharodon carcharias) population off California, USA. PLoS One 9:e98078. doi: 10.1371/ journal.pone.0098078

Burgess, G. H., and Callahan, M. (1996). "Worldwide patterns of white shark attacks on humans," in Great White Sharks: the Biology of Carcharodon carcharias, eds A. P. Klimley and D. G. Ainley (San Diego, CA: Academic Press), 457-469.

Carlisle, A. B., Kim, S. L., Semmens, B. X., Madigan, D. J., Jorgensen, S. J., Perle, C. R., et al. (2012). Using stable isotope analysis to understand the migration and trophic ecology of northeastern pacific white sharks (Carcharodon carcharias). PLoS One 7:e30492. doi: 10.1371/journal.pone.0030492

Carlson, J. K., Goldman, K. J., and Lowe, C. G. (2004). Metabolism, energetic demand, and endothermy. Biol. Sharks Relat. 10, 269-286. doi: 10.1093/icb/ icw019

Chapple, T. K., and Botsford, L. W. (2013). A comparison of linear demographic models and fraction of lifetime egg production for assessing sustainability in sharks. Conserv. Biol. 27, 560-568. doi: 10.1111/cobi. 12053

Chapple, T. K., Chambert, T., Kanive, P. E., Jorgensen, S. J., Rotella, J. J., Anderson, S. D., et al. (2016). A novel application of multi-event modeling to estimate class segregation in a highly migratory oceanic vertebrate. Ecology 97, 3494-3502. doi: 10.1002/ecy.1589

Chapple, T. K., Gleiss, A. C., Jewell, O. J. D., Wikelski, M., and Block, B. A. (2015). Tracking sharks without teeth: a non-invasive rigid tag attachment for large predatory sharks. Anim. Biotelem. 3:14. doi: 10.1186/s40317-015-0044-9

Chapple, T. K., Jorgensen, S. J., Anderson, S. D., Kanive, P. E., Klimley, A. P., Botsford, L. W., et al. (2011). A first estimate of white shark, Carcharodon carcharias, abundance off central California. Biol. Lett. 7, 581-583. doi: 10.1098/ rsbl.2011.0124

Chin, A., Kyne, P. M., Walker, T. I., and McAuley, R. B. (2010). An integrated risk assessment for climate change: analysing the vulnerability of sharks and rays on Australia's Great Barrier Reef. Glob. Chang. Biol. 16, 1936-1953. doi: 10.1111/j.1365-2486.2009.02128.x

Chivell, W. (2018). "The tourism industry and shark welfare," in Tourism and Animal Welfare, eds N. Carr and D. M. Broom (Wallingford: CABI), 97-101.

Christiansen, H. M., Fisk, A. T., and Hussey, N. E. (2015). Incorporating stable isotopes into a multidisciplinary framework to improve data inference and their conservation and management application. Afr. J. Mar. Sci. 37, 189-197. doi: 10.2989/1814232X.2015.1039583

Christiansen, H. M., Lin, V., Tanaka, S., Velikanov, A., Mollet, H. F., Wintner, S. P., et al. (2014). The last frontier: catch records of white sharks (Carcharodon 
carcharias) in the Northwest Pacific Ocean. PLoS One 9:e94407. doi: 10.1371/ journal.pone.0094407

Cione, A., and Barla, M. J. (2008). Causes and contrasts in current and past distribution of the white shark (Lamniformes: Carcharodon carcharias) off southeastern South America. Rev. Mus. Argent. Cienc. Nat. Nueva Ser. 10, 175-184. doi: 10.22179/REVMACN.10.275

Cisneros-Montemayor, A. M., Barnes-Mauthe, M., Al-Abdulrazzak, D., NavarroHolm, E., and Sumaila, U. R. (2013). Global economic value of shark ecotourism: implications for conservation. Oryx 47, 381-388. doi: 10.1017/ S0030605312001718

Cliff, G., Dudley, S. F. J., and Davis, B. (1989). Sharks caught in the protective gill nets off Natal, South Africa. 2. The great white shark Carcharodon carcharias (Linnaeus). S. Afr. J. Mar. Sci. 8, 131-144. doi: 10.2989/02577618909504556

Compagno, L. (1991). Government protection for the great white shark (Carcharodon carcharias) in South Africa. S. Afr. J. Mar. Sci. 87, 284-285.

Cooke, S. J., Brownscombe, J. W., Raby, G. D., Broell, F., Hinch, S. G., Clark, T. D., et al. (2016a). Remote bioenergetics measurements in wild fish: opportunities and challenges. Comp. Biochem. Physiol. A Mol. Integr. Physiol. 202, 23-37. doi: 10.1016/j.cbpa.2016.03.022

Cooke, S. J., Wilson, A. D. M., Elvidge, C. K., Lennox, R. J., Jepsen, N., Colotelo, A. H., et al. (2016b). Ten practical realities for institutional animal care and use committees when evaluating protocols dealing with fish in the field. Rev. Fish Biol. Fish. 26, 123-133. doi: 10.1007/s11160-015-9413-y

Crossley, R., Collins, C. M., Sutton, S. G., and Huveneers, C. (2014). Public perception and understanding of shark attack mitigation measures in Australia. Hum. Dimens. Wildl. 19, 154-165. doi: 10.1080/10871209.2014.844289

Curtis, T. H., Bruce, B. D., Cliff, G., Dudley, S. F. J., Klimley, A. P., Kock, A. A., et al. (2012). "Responding to the risk of white shark attack: updated statistics, prevention, control methods, and recommendations," in Global Perspectives on the Biology and Life History of the Great White Shark, ed. M. L. Domeier (Boca Raton, FL: CRC Press), 477-510.

Curtis, T. H., McCandless, C. T., Carlson, J. K., Skomal, G. B., Kohler, N. E., Natanson, L. J., et al. (2014). Seasonal distribution and historic trends in abundance of white sharks, Carcharodon carcharias, in the western North Atlantic Ocean. PLoS One 9:e99240. doi: 10.1371/journal.pone.0099240

Curtis, T. H., Metzger, G., Fischer, C., McBride, B., McCallister, M., Winn, L. J., et al. (2018). First insights into the movements of young-of-the-year white sharks (Carcharodon carcharias) in the western North Atlantic Ocean. Sci. Rep. 8:10794. doi: 10.1038/s41598-018-29180-5

de Juan, S., and Lleonart, J. (2010). A conceptual framework for the protection of vulnerable habitats impacted by fishing activities in the Mediterranean high seas. Ocean Coast. Manag. 53, 717-723. doi: 10.1016/j.ocecoaman.2010.10.005

De Vos, A., Justin, O., Riain, M., Meÿer, M. A., Kotze, P. G. H., and Kock, A. A. (2015a). Behavior of Cape fur seals (Arctocephalus pusillus pusillus) in response to spatial variation in white shark (Carcharodon carcharias) predation risk. Mar. Mamm. Sci. 31, 1234-1251. doi: 10.1111/mms.12215

De Vos, A., Justin, O., Riain, M., Meyer, M. A., Kotze, P. G. H., and Kock, A. A. (2015b). Behavior of Cape fur seals (Arctocephalus pusillus pusillus) in relation to temporal variation in predation risk by white sharks (Carcharodon carcharias) around a seal rookery in False Bay, South Africa. Mar. Mamm. Sci. 31, 1118-1131. doi: 10.1111/mms.12208

Del Raye, G., and Weng, K. (2015). An aerobic scope-based habitat suitability index for predicting the effects of multi-dimensional climate change stressors on marine teleosts. Deep Sea Res. 113, 280-290. doi: 10.1016/j.dsr2.2015. 01.014

Dewar, H., Domeier, M., and Nasby-Lucas, N. (2004). Insights into young of the year white shark, Carcharodon carcharias, behavior in the Southern California Bight. Environ. Biol. Fishes 70, 133-143. doi: 10.1023/B:EBFI.0000029343. $54027.6 \mathrm{a}$

Dewar, H., Eguchi, T., Hyde, J., Kinzey, D., Kohin, S., Moore, J., et al. (2013). Status Review of the Northeastern Pacific Population of White Sharks (Carcharodon carcharias) Under the Endangered Species Act. Washington, DC: National Oceanic and Atmospheric Administration.

Dicken, M. L., and Booth, A. J. (2013). Surveys of white sharks (Carcharodon carcharias) off bathing beaches in Algoa Bay, South Africa. Mar. Freshw. Res. 64, 530-539. doi: 10.1071/MF12336

Dickson, K. A., Gregorio, M. O., Gruber, S. J., Loefler, K. L., Tran, M., and Terrell, C. (1993). Biochemical indices of aerobic and anaerobic capacity in muscle tissues of California elasmobranch fishes differing in typical activity level. Mar. Biol. 117, 185-193. doi: 10.1007/BF00345662

Dillingham, P. W., Moore, J. E., Fletcher, D., Cortés, E., Curtis, K. A., James, K. C., et al. (2016). Improved estimation of intrinsic growth rmax for longlived species: integrating matrix models and allometry. Ecol. Appl. 26, 322-333. doi: 10.1890/14-1990

Domeier, M. L. (2012a). "A new life-history hypothesis for white sharks, Carcharodon carcharias," in the Northeastern Pacific. In: Global Perspectives on the Biology and Life History of the White Shark, ed. M. L. Domeier (Boca Raton, FL: CRC Press), 199-224. doi: 10.1201/b11532-19

Domeier, M. L. (2012b). Global Perspectives on the Biology and Life History of the White Shark. Boca Raton, FL: CRC Press. doi: 10.1201/b11532

Domeier, M. L., and Nasby-Lucas, N. (2013). Two-year migration of adult female white sharks (Carcharodon carcharias) reveals widely separated nursery areas and conservation concerns. Anim. Biotelem. 1:2. doi: 10.1186/2050-3385-1-2

Duffy, C., Francis, M. P., Manning, M. J., and Bonfil, R. (2012). "Regional population connectivity, oceanic habitat, and return migration revealed by satellite tagging of white sharks, Carcharodon carcharias, at New Zealand aggregation sites," in Global Perspectives on the Biology and Life History of the White Shark, ed. M. L. Domeier (Boca Raton, FL: CRC Press), 301-318.

Dulvy, N. K., Fowler, S. L., Musick, J. A., Cavanagh, R. D., Kyne, P. M., Harrison, L. R., et al. (2014). Extinction risk and conservation of the world's sharks and rays. eLife 3:e00590. doi: 10.7554/eLife.00590

Engelbrecht, T., Kock, A., Waries, S., and O’Riain, M. J. (2017). Shark spotters: successfully reducing spatial overlap between white sharks (Carcharodon carcharias) and recreational water users in False Bay, South Africa. PLoS One 12:e0185335. doi: 10.1371/journal.pone.0185335

Estrada, J. A., Rice, A. N., Natanson, L. J., and Skomal, G. B. (2006). Use of isotopic analysis of vertebrae in reconstructing ontogenetic feeding ecology in white sharks. Ecology 87, 829-834. doi: 10.1890/0012-9658(2006)87[829:UOIAOV]2. $0 . \mathrm{CO} ; 2$

Fergusson, I., Compagno, L. J. V., and Marks, M. (2009). Carcharodon carcharias. The IUCN Red List of Threatened Species 2009: e.T3855A10133872. Available at: http://dx.doi.org/10.2305/IUCN.UK.2009-2.RLTS.T3855A10133872.en [accessed July 19, 2018]. doi: 10.2305/IUCN.UK.2009-2.RLTS. T3855A10133872.en

Fergusson, I. K. (1996). "Distribution and autecology of the white shark in the eastern North Atlantic Ocean and the Mediterranean Sea," in Great White Sharks: the Biology of Carcharodon carcharias, eds A. P. Klimley and D. G. Ainley (San Diego, CA: Academic Press), 321-345.

Fergusson, I. K. (2002). "Occurrence and biology of the great white shark, Carcharodon carcharias, in the Central Mediterranean Sea: a review," in Proceedings of the 4th European Elasmobranch Association Meeting, Livorno, $7-23$.

Fergusson, I. K., Compagno, L. J. V., and Marks, M. A. (2000). Predation by white sharks Carcharodon carcharias (Chondrichthyes: Lamnidae) upon chelonians, with new records from the Mediterranean Sea and a first record of the ocean sunfish Mola mola (Osteichthyes: Molidae) as stomach contents. Environ. Biol. Fishes 58, 447-453. doi: 10.1023/A:1007639324360

Ferretti, F., Jorgensen, S., Chapple, T. K., De Leo, G., and Micheli, F. (2015). Reconciling predator conservation with public safety. Front. Ecol. Environ. 13:412-417. doi: 10.1890/150109

Fitzpatrick, J. L., Kempster, R. M., Daly-Engel, T. S., Collin, S. P., and Evans, J. P. (2012). Assessing the potential for post-copulatory sexual selection in elasmobranchs. J. Fish Biol. 80, 1141-1158. doi: 10.1111/j.1095-8649.2012. 03256.x

Ford, J. K. B., Ellis, G. M., Barrett-Lennard, L. G., Morton, A. B., Palm, R. S., and Balcomb, K. C. III (1998). Dietary specialization in two sympatric populations of killer whales (Orcinus orca) in coastal British Columbia and adjacent waters. Can. J. Zool. 76, 1456-1471. doi: 10.1139/z98-089

Francis, M. P. (1996). "Observations on a pregnant white shark with a review of reproductive biology," in Great White Sharks: The Biology of Carcharodon carcharias, eds A. P. Klimley and D. G. Ainley (San Diego, CA: Academic Press), 157-172.

Francis, M. P., Duffy, C. A. J., Bonfil, R., and Manning, M. J. (2012). "The third dimension: vertical habitat use by white sharks, Carcharodon carcharias," in New Zealand and in Oceanic and Tropical Waters of the Southwest Pacific Ocean" in Global Perspectives on the Biology and Life 
History of the White Shark, ed. M. L. Domeier (Boca Raton, FL: CRC Press), 319-342.

French, G. C. A., Rizzuto, S., Stürup, M., Inger, R., Barker, S., van Wyk, J. H., et al. (2018). Sex, size and isotopes: cryptic trophic ecology of an apex predator, the white shark Carcharodon carcharias. Mar. Biol. 165:102. doi: 10.1007/s00227018-3343-x

French, G. C. A., Stürup, M., Rizzuto, S., Van Wyk, J. H., Edwards, D., Dolan, R. W., et al. (2017). The tooth, the whole tooth and nothing but the tooth: tooth shape and ontogenetic shift dynamics in the white shark Carcharodon carcharias. J. Fish Biol. 91, 1032-1047. doi: 10.1111/jfb.13396

Gallagher, A. J., and Huveneers, C. (2018). Emerging challenges to shark-diving tourism. Mar. Policy 96, 9-12. doi: 10.1016/j.marpol.2018.07.009

Gaxiola-Castro, G. J., Field, R. M., Suryan, S. R., Schneider, C., Barceló, K., Sakuma, S., et al. (2015). State of the California current 2014-15: impacts of the warm-water" Blob". CalCOFI Rep. 56, 31-68.

Gubili, C., Duffy, C., Cliff, G., Wintner, S., Shivji, M. S., Chapman, D. D., et al. (2012). "Application of molecular genetics for conservation of the great white shark, Carcharodon carcharias, L. 1758," in Global Perspectives on the Biology and Life History of the White Shark, ed. M. L. Domeier (Boca Raton, FL: CRC Press), 357-380.

Hammerschlag, N., Cooke, S. J., Gallagher, A. J., and Godley, B. J. (2014). Considering the fate of electronic tags: interactions with stakeholders and user responsibility when encountering tagged aquatic animals. Methods Ecol. Evol. 5, 1147-1153. doi: 10.1111/2041-210X.12248

Hammerschlag, N., Meÿer, M., Seakamela, S. M., Kirkman, S., Fallows, C., and Creel, S. (2017). Physiological stress responses to natural variation in predation risk: evidence from white sharks and seals. Ecology 98, 3199-3210. doi: 10.1002/ ecy. 2049

Hara, M., Maharaj, I., and Pithers, L. (2003). Marine-based tourism in Gansbaai: a socio-economic study. Final Rep. Dep. Environ. Aff. Tour. 55. doi: 10.13140/RG. 2.1.3845.7046

Harrison, A.-L., Costa, D. P., Winship, A. J., Benson, S. R., Bograd, S. J., Antolos, M., et al. (2018). The political biogeography of migratory marine predators. Nat. Ecol. Evol. 2, 1571-1578. doi: 10.1038/s41559-018-0646-8

Hays, G. C., Ferreira, L. C., Sequeira, A. M. M., Meekan, M. G., Duarte, C. M., Bailey, H., et al. (2016). Key questions in marine megafauna movement ecology. Trends Ecol. Evol. 31, 463-475. doi: 10.1016/j.tree.2016.02.015

Hazen, E. L., Maxwell, S. M., Bailey, H., Bograd, S. J., Hamann, M., Gaspar, P., et al. (2012). Ontogeny in marine tagging and tracking science: technologies and data gaps. Mar. Ecol. Prog. Ser. 457, 221-240. doi: 10.3354/meps09857

Heady, W. N., and Moore, J. W. (2013). Tissue turnover and stable isotope clocks to quantify resource shifts in anadromous rainbow trout. Oecologia 172, 21-34. doi: 10.1007/s00442-012-2483-9

Hewitt, A. M., Kock, A. A., Booth, A. J., and Griffiths, C. L. (2018). Trends in sightings and population structure of white sharks, Carcharodon carcharias, at Seal Island, False Bay, South Africa, and the emigration of subadult female sharks approaching maturity. Environ. Biol. Fish. 101, 39-54. doi: 10.1007/ s10641-017-0679-x

Hillary, R. M., Bravington, M. V., Patterson, T. A., Grewe, P., Bradford, R., Feutry, P., et al. (2018). Genetic relatedness reveals total population size of white sharks in eastern Australia and New Zealand. Sci. Rep. 8:2661. doi: 10.1038/ s41598-018-20593-w

Hoenig, J. M., Gruber, S. H., Pratt, H., and Taniuchi, T. (1990). Elasmobranchs as Living Resources: Advances in the Biology, Ecology, Systematics, and the Status of the Fisheries. Washington, DC: National Marine Fisheries Service.

Holden, M. J. (1974). "Problems in the rational exploitation of elasmobranch populations and some suggested solutions," in Sea Fisheries Research, ed. F. R. Harden-Jones (London: Elek Science), 117-137.

Holland, K. N., Wetherbee, B. M., Lowe, C. G., and Meyer, C. G. (1999). Movements of tiger sharks (Galeocerdo cuvier) in coastal Hawaiian waters. Mar. Biol. 134, 665-673. doi: 10.1038/s41598-018-23006-0

Hussey, N. E., MacNeil, M. A., Siple, M. C., Popp, B. N., Dudley, S. F. J., and Fisk, A. T. (2015). Expanded trophic complexity among large sharks. Food Webs 4, 1-7. doi: 10.1016/j.fooweb.2015.04.002

Hussey, N. E., McCann, H. M., Cliff, G., Dudley, S. F. J., Wintner, S. P., and Fisk, A. T. (2012). "'Size-based analysis of diet and trophic position of the white shark, Carcharodon carcharias," in South African Waters" in Global Perspectives on the Biology and Life History of the White Shark, ed. M. L. Domeier (Boca Raton, FL: CRC Press), 27-50.

Huveneers, C., Meekan, M. G., Apps, K., Ferreira, L. C., Pannell, D., and Vianna, G. M. S. (2017). The economic value of shark-diving tourism in Australia. Rev. Fish Biol. Fish. 27, 665-680. doi: 10.1007/s11160-0179486-x

Huveneers, C., Rogers, P. J., Beckmann, C., Semmens, J., Bruce, B., and Seuront, L. (2013a). The effects of cage-diving activities on the fine-scale swimming behaviour and space use of white sharks. Mar. Biol. 160, 2863-2875. doi: 10.1007/s00227-013-2277-6

Huveneers, C., Rogers, P. J., Semmens, J., Beckmann, C., Kock, A. A., Page, B., et al. (2013b). Effects of an electric field on white sharks: in situ testing of an electric deterrent. PLoS One 8:e62730. doi: 10.1371/journal.pone.0062730

Huveneers, C., Watanabe, Y. Y., Payne, N. L., and Semmens, J. M. (2018a). Interacting with wildlife tourism increases activity of white sharks. Conserv. Physiol. 6:coy019. doi: 10.1093/conphys/coy019

Huveneers, C., Whitmarsh, S., Thiele, M., Meyer, L., Fox, A., and Bradshaw, C. J. A. (2018b). Effectiveness of five personal shark-bite deterrents for surfers. PeerJ 6:e5554. doi: 10.7717/peerj.5554

Irion, D. T., Noble, L. R., Kock, A. A., Gennari, E., Dicken, M. L., Hewitt, A. M., et al. (2017). Pessimistic assessment of white shark population status in South Africa: comment on Andreotti et al.(2016). Mar. Ecol. Prog. Ser. 577, 251-255. doi: 10.3354/meps12283

Jewell, O. J. D., Wcisel, M. A., Gennari, E., Towner, A. V., Bester, M. N., Johnson, R. L., et al. (2011). Effects of smart position only (SPOT) tag deployment on white sharks Carcharodon carcharias in South Africa. PLoS One 6:e27242. doi: 10.1371/journal.pone.0027242

Jorgensen, S. J., Arnoldi, N. S., Estess, E. E., Chapple, T. K., Rückert, M., Anderson, S. D., et al. (2012). Eating or meeting? Cluster analysis reveals intricacies of white shark (Carcharodon carcharias) migration and offshore behavior. PLoS One 7:e47819. doi: 10.1371/journal.pone.0047819

Jorgensen, S. J., Gleiss, A. C., Kanive, P. E., Chapple, T. K., Anderson, S. D., Ezcurra, J. M., et al. (2015). In the belly of the beast: resolving stomach tag data to link temperature, acceleration and feeding in white sharks (Carcharodon carcharias). Anim. Biotelem. 3:52. doi: 10.1186/s40317-015-0071-6

Jorgensen, S. J., Reeb, C. A., Chapple, T. K., Anderson, S., Perle, C., Van Sommeran, S. R., et al. (2009). Philopatry and migration of pacific white sharks. Proc. R. Soc. B Biol. Sci. 277, 679-688. doi: 10.1098/rspb.2009.1155

Kabasakal, H. (2014). The status of the great white shark (Carcharodon carcharias) in Turkey's waters. Mar. Biodivers. Rec. 7, 1-8. doi: 10.1017/S1755267214000980

Kempster, R. M., Egeberg, C. A., Hart, N. S., Ryan, L., Chapuis, L., Kerr, C., et al. (2016). How close is too close? The effect of non-lethal electric fields on white shark behaviour. PLoS One 11:e0157717. doi: 10.1371/journal.pone.0157717

Kim, S. L., Tinker, M. T., Estes, J. A., and Koch, P. L. (2012). Ontogenetic and among-individual variation in foraging strategies of northeast pacific white sharks based on stable isotope analysis. PLoS One 7:e45068. doi: 10.1371/ journal.pone. 0045068

Kitchell, J. F., Essington, T. E., Boggs, C. H., Schindler, D. E., and Walters, C. J. (2002). The role of sharks and longline fisheries in a pelagic ecosystem of the central Pacific. Ecosystems 5, 202-216. doi: 10.1007/s10021-001-0065-5

Kock, A., and Johnson, R. L. (2006). "White shark abundance: not a causative factor in numbers of shark bite incidents," in Finding a Balance: White Shark Conservation and Recreational Safety in the Inshore Waters of Cape Town, South Africa, eds D. C. Nel and T. P. Peschak (Cape Town: WWF South Africa), $1-19$.

Kock, A., Titley, S., Petersen, W., Sikweyiya, M., Tsotsobe, S., Colenbrander, D., et al. (2012). "A pioneering shark safety program in cape town, South Africa," in Global Perspectives on the Biology and Life History of the White Shark, ed. M. L. Domeier (Boca Raton, FL: CRC Press), 447-466.

Kock, A. A., O'Riain, M. J., Mauff, K., Meÿer, M., Kotze, D., and Griffiths, C. (2013). Residency, habitat use and sexual segregation of white sharks, Carcharodon carcharias in False Bay, South Africa. PLoS One 8:e55048. doi: 10.1371/journal. pone. 0055048

Koehn, J. D., Hobday, A. J., Pratchett, M. S., and Gillanders, B. M. (2011). Climate change and Australian marine and freshwater environments, fishes and fisheries: synthesis and options for adaptation. Mar. Freshw. Res. 62, 1148-1164. doi: 10.1071/MF11139 
Laroche, K. R., Kock, A. A., Dill, L. M., and Oosthuizen, H. (2007). Effects of provisioning ecotourism activity on the behaviour of white sharks Carcharodon carcharias. Mar. Ecol. Prog. Ser. 338, 199-209. doi: 10.3354/meps338199

Larson, S. E., Daly-Engel, T. S., and Phillips, N. M. (2017). Review of current conservation genetic analyses of Northeast Pacific sharks. Adv. Mar. Biol. 77, 79-110. doi: 10.1016/bs.amb.2017.06.005

Lowe, C. G., Blasius, M. E., Jarvis, E. T., Mason, T. J., Goodmanlowe, G. D., and O'Sullivan, J. B. (2012). "Historic fishery interactions with white sharks in the Southern California Bight," in Global Perspectives on the Biology and Life History of the White Shark, ed. M. L. Domeier (Boca Raton, FL: CRC Press), 169-186.

Lyons, K., Jarvis, E. T., Jorgensen, S. J., Weng, K., O’Sullivan, J., Winkler, C., et al. (2013). The degree and result of gillnet fishery interactions with juvenile white sharks in southern California assessed by fishery-independent and-dependent methods. Fish. Res. 147, 370-380. doi: 10.1016/j.fishres.2013.07.009

McKinney, M. A., Dean, K., Hussey, N. E., Cliff, G., Wintner, S. P., Dudley, S. F. J., et al. (2016). Global versus local causes and health implications of high mercury concentrations in sharks from the east coast of South Africa. Sci. Total Environ. 541, 176-183. doi: 10.1016/j.scitotenv.2015.09.074

McPherson, J. M., and Myers, R. A. (2009). How to infer population trends in sparse data: examples with opportunistic sighting records for great white sharks. Divers. Distrib. 15, 880-890. doi: 10.1111/j.1472-4642.2009.00596.x

Meeuwig, J. J., and Ferreira, L. C. (2014). Moving beyond lethal programs for shark hazard mitigation. Anim. Conserv. 17, 297-298. doi: 10.1111/acv.12154

Meyer, L., Pethybridge, H., Nichols, P. D., Beckmann, C., Bruce, B. D., Werry, J. M., et al. (2017). Assessing the functional limitations of lipids and fatty acids for diet determination: the importance of tissue type, quantity, and quality. Front. Mar. Sci. 4:369. doi: 10.3389/fmars.2017.00369

Morey, G., Martínez, M., Massutí, E., and Moranta, J. (2003). The occurrence of white sharks, Carcharodon carcharias, around the Balearic Islands (western Mediterranean Sea). Environ. Biol. Fishes 68, 425-432. doi: 10.1023/B:EBFI. 0000005789.83761.d8

Mull, C. G., Blasius, M. E., O’Sullivan, J. B., and Lowe, C. G. (2012). "Heavy metals, trace elements, and organochlorine contaminants in muscle and liver tissue of juvenile white sharks, Carcharodon carcharias, from the Southern California Bight," in Global Perspectives on the Biology and Life History of the White Shark, ed. M. L. Domeier (Boca Raton, FL: CRC Press), 59-75.

Mull, C. G., Lyons, K., Blasius, M. E., Winkler, C., O'Sullivan, J. B., and Lowe, C. G. (2013). Evidence of maternal offloading of organic contaminants in white sharks (Carcharodon carcharias). PLoS One 8:e62886. doi: 10.1371/journal. pone.0062886

Munroe, S., Meyer, L., and Heithaus, M. (2018). "Dietary biomarkers in shark foraging and movement ecology," in Shark Research: Emerging Technologies \& Applications for the Field and Laboratory, eds J. Carrier, M. Heithaus, and C. Simpfendorfer (Boca Raton, FL: CRC Press).

Muter, B. A., Gore, M. L., Gledhill, K. S., Lamont, C., and Huveneers, C. (2013). Australian and US news media portrayal of sharks and their conservation. Conserv. Biol. 27, 187-196. doi: 10.1111/j.1523-1739.2012.01952.x

O'Connell, C. P., Andreotti, S., Rutzen, M., Me?er, M., and Matthee, C. A. (2018). Testing the exclusion capabilities and durability of the Sharksafe Barrier to determine its viability as an eco-friendly alternative to current shark culling methodologies. Aquat. Conserv. Mar. Freshw. Ecosyst. 28, 252-258. doi: 10. $1002 /$ aqc. 2803

O’Leary, S. J., Feldheim, K. A., and Chapman, D. D. (2013). Novel microsatellite loci for white, Carcharodon carcharias and sand tiger sharks, Carcharias taurus (order Lamniformes). Conserv. Genet. Resour. 5, 627-629. doi: 10.1007/s12686013-9866-Z

O’Leary, S. J., Feldheim, K. A., Fields, A. T., Natanson, L. J., Wintner, S., Hussey, N., et al. (2015). Genetic diversity of white sharks, Carcharodon carcharias, in the Northwest Atlantic and southern Africa. J. Hered. 106, 258-265. doi: 10.1093/ jhered/esv001

Oñate-González, E. C., Rocha-Olivares, A., Saavedra-Sotelo, N. C., and SosaNishizaki, O. (2015). Mitochondrial genetic structure and matrilineal origin of white sharks, Carcharodon carcharias, in the Northeastern Pacific: implications for their conservation. J. Hered. 106, 347-354. doi: 10.1093/jhered/ esv034

Oñate-González, E. C., Sosa-Nishizaki, O., Herzka, S. Z., Lowe, C. G., Lyons, K., Santana-Morales, O., et al. (2017). Importance of Bahia Sebastian Vizcaino as a nursery area for white sharks (Carcharodon carcharias) in the Northeastern Pacific: a fishery dependent analysis. Fish. Res. 188, 125-137. doi: 10.1016/j. fishres.2016.12.014

Pardini, A. T., Jones, C. S., Noble, L. R., Kreiser, B., Malcolm, H., Bruce, B. D., et al. (2001). Sex-biased dispersal of great white sharks. Nature 412, 139-140. doi: $10.1038 / 35084125$

Pauly, D., Christensen, V., and Walters, C. (2000). Ecopath, Ecosim, and Ecospace as tools for evaluating ecosystem impact of fisheries. ICES J. Mar. Sci. 57, 697-706. doi: 10.1006/jmsc.2000.0726

Payne, N. L., Meyer, C. G., Smith, J. A., Houghton, J. D. R., Barnett, A., Holmes, B. J., et al. (2018). Combining abundance and performance data reveals how temperature regulates coastal occurrences and activity of a roaming apex predator. Glob. Chang. Biol. 24, 1884-1893. doi: 10.1111/gcb.14088

Payne, N. L., Snelling, E. P., Fitzpatrick, R., Seymour, J., Courtney, R., Barnett, A., et al. (2015). A new method for resolving uncertainty of energy requirements in large water breathers: the 'mega-flume' seagoing swim-tunnel respirometer. Methods Ecol. Evol. 6, 668-677. doi: 10.1111/2041-210X.12358

Pecl, G. T., Araújo, M. B., Bell, J. D., Blanchard, J., Bonebrake, T. C., Chen, I.C., et al. (2017). Biodiversity redistribution under climate change: impacts on ecosystems and human well-being. Science 355:eaai9214. doi: 10.1126/science. aai9214

Pepin-Neff, C., and Wynter, T. (2018). Shark bites and shark conservation: an analysis of human attitudes following shark bite incidents in two locations in Australia. Conserv. Lett. 11:e12407. doi: 10.1111/conl.12407

Peterson, W., Robert, M., and Bond, N. (2015). The warm blob continues to dominate the ecosystem of the northern California current. PICES Press 23, 44-46.

Pethybridge, H. R., Parrish, C. C., Bruce, B. D., Young, J. W., and Nichols, P. D. (2014). Lipid, fatty acid and energy density profiles of white sharks?: insights into the feeding ecology and ecophysiology of a complex top predator. PLoS One 9:e97877. doi: 10.1371/journal.pone.0097877

Polo-Silva, C. J., Galván-Magaña, F., and Delgado-Huertas, A. (2012). Trophic inferences of blue shark (Prionace glauca) in the Mexican Pacific from stable isotope analysis in teeth. Rapid Commun. Mass Spectrom. 26, 1631-1638. doi: $10.1002 / \mathrm{rcm} .6275$

Queiroz, N., Humphries, N. E., Mucientes, G., Hammerschlag, N., Lima, F. P., Scales, K. L., et al. (2016). Ocean-wide tracking of pelagic sharks reveals extent of overlap with longline fishing hotspots. Proc. Natl. Acad. Sci. U.S.A. 113, 1582-1587. doi: 10.1073/pnas.1510090113

Ramirez-Amaro, S. R., Cartamil, D., Galvan-Magaña, F., Gonzalez-Barba, G., Graham, J. B., Carrera-Fernandez, M., et al. (2013). The artisanal elasmobranch fishery of the Pacific coast of Baja California Sur, Mexico, management implications. Sci. Mar. 77, 473-487. doi: 10.3989/scimar.03 $817.05 \mathrm{~A}$

Reid, D. D., Robbins, W. D., and Peddemors, V. M. (2011). Decadal trends in shark catches and effort from the New South Wales, Australia, Shark Meshing Program 1950-2010. Mar. Freshw. Res. 62, 676-693. doi: 10.1071/MF10162

Rizzari, J. R., Semmens, J. M., Fox, A., and Huveneers, C. (2017). Observations of marine wildlife tourism effects on a non-focal species. J. Fish Biol. 91, 981-988. doi: $10.1111 /$ jfb.13389

Robbins, W. D., Huveneers, C., Parra, G. J., Möller, L., and Gillanders, B. M. (2017). Anthropogenic threat assessment of marine-associated fauna in Spencer Gulf, South Australia. Mar. Policy 81, 392-400. doi: 10.1016/j.marpol.2017.03.036

Sabatier, E., and Huveneers, C. (2018). Changes in media portrayal of humanwildlife conflict during successive fatal shark bites. Conserv. Soc. 16, 338-350. doi: 10.4103/cs.cs_18_5

Saídi, B., Bradai, M. N., Bouain, A., Guelorget, O., and Capape, C. (2005). Capture of a pregnant female white shark, Carcharodon carcharias (Lamnidae) in the Gulf of Gabes (southern Tunisia, central Mediterranean) with comments on oophagy in sharks. Cybium 29, 303-307.

Santana-Morales, O., Sosa-Nishizaki, O., Escobedo-Olvera, M. A., OñateGonzález, E. C., O'Sullivan, J. B., and Cartamil, D. (2012). "“'Incidental catch and ecological observations of juvenile white sharks, Carcharodon carcharias," in Western Baja California, Mexico: Conservation Implications" in Global Perspectives on the Biology and Life History of the White Shark, ed. M. L. Domeier (Boca Raton, FL: CRC Press), 187-198.

Sato, K., Nakamura, M., Tomita, T., Toda, M., Miyamoto, K., and Nozu, R. (2016). How great white sharks nourish their embryos to a large size: evidence of 
lipid histotrophy in lamnoid shark reproduction. Biol. Open 5, 1211-1215. doi: 10.1242/bio.017939

Simpfendorfer, C. A., Kyne, P. M., Noble, T. H., Goldsbury, J., Basiita, R. K., Lindsay, R., et al. (2016). Environmental DNA detects Critically Endangered largetooth sawfish in the wild. Endanger. Species Res. 30, 109-116. doi: 10.3354/ esr00731

Skomal, G. B., Braun, C. D., Chisholm, J. H., and Thorrold, S. R. (2017). Movements of the white shark Carcharodon carcharias in the North Atlantic Ocean. Mar. Ecol. Prog. Ser. 580, 1-16. doi: 10.3354/meps 12306

Skomal, G. B., Chisholm, J., and Correia, S. (2012). "Implications of increasing pinniped populations on the diet and abundance of white sharks off the coast of Massachusetts," in Global Perspectives on the Biology and Life History of the White Shark, ed. M. L. Domeier (Boca Raton, FL: CRC Press), 405-418.

Skomal, G. B., Hoyos-Padilla, E. M., Kukulya, A. L., and Stokey, R. P. (2015). Subsurface observations of white shark predatory behaviour using an autonomous underwater vehicle. J. Fish Biol. 87, 1293-1312. doi: 10.1111/jfb. 12828

Soldo, A., and Dulčić, J. (2005). New record of a great white shark, Carcharodon carcharias (Lamnidae) from the eastern Adriatic Sea. Cybium 29, 89-90.

Soldo, A., and Jardas, I. (2002). Occurrence of great white shark, Carcharodon carcharias (Linnaeus, 1758) and basking shark, Cetorhinus maximus (Gunnerus, 1165) in the Eastern Adriatic and their protection. Period. Biol. 104, 195-201.

Somero, G. N. (2010). The physiology of climate change: how potentials for acclimatization and genetic adaptation will determine 'winners' and 'losers'. J. Exp. Biol. 213, 912-920. doi: 10.1242/jeb.037473

Sosa-Nishizaki, O., Morales-Bojoìrquez, E., Nasby-Lucas, N., Onpate-Gonzailez, E. C., and Domeier, M. L. (2012). "Problems with photo identification as a method of estimating abundance of White Sharks (Carcharodon carcharias) an example from Guadalupe Island, Mexico," in Global Perspectives on the Biology and Life History of the White Shark, ed. M. L. Domeier (Boca Raton, FL: CRC Press), 393-404. doi: 10.1080/17451000.2012.708043

Sperone, E., Micarelli, P., Andreotti, S., Brandmayr, P., Bernabò, I., Brunelli, E., et al. (2012a). Surface behaviour of bait-attracted white sharks at Dyer Island (South Africa). Mar. Biol. Res. 8, 982-991.

Sperone, E., Parise, G., Leone, A., Milazzo, C., Circosta, V., Santoro, G., et al. (2012b). Spatiotemporal patterns of distribution of large predatory sharks in Calabria (central Mediterranean, southern Italy). Acta Adriat. Int. J. Mar. Sci. 53, 13-23. doi: 10.3354/ab00648

Sulikowski, J. A., Wheeler, C. R., Gallagher, A. J., Prohaska, B. K., Langan, J. A., and Hammerschlag, N. (2016). Seasonal and life-stage variation in the reproductive ecology of a marine apex predator, the tiger shark Galeocerdo cuvier, at a protected female-dominated site. Aquat. Biol. 24, 175-184.

Towner, A. V., Leos-Barajas, V., Langrock, R., Schick, R. S., Smale, M. J., Kaschke, T., et al. (2016). Sex-specific and individual preferences for hunting strategies in white sharks. Funct. Ecol. 30, 1397-1407. doi: 10.1111/1365-2435. 12613

Towner, A. V., Wcisel, M. A., Reisinger, R. R., Edwards, D., and Jewell, O. J. D. (2013). Gauging the threat: the first population estimate for white sharks in
South Africa using photo identification and automated software. PLoS One 8:e66035. doi: 10.1371/journal.pone.0066035

Valavanis, V. D., Pierce, G. J., Zuur, A. F., Palialexis, A., Saveliev, A., Katara, I., et al. (2008). "Modelling of essential fish habitat based on remote sensing, spatial analysis and GIS," in Essential Fish Habitat Mapping in the Mediterranean, ed. V. D. Valavanis (Berlin: Springer Science \& Business Media), 5-20.

Vennemann, T. W., Hegner, E., Cliff, G., and Benz, G. W. (2001). Isotopic composition of recent shark teeth as a proxy for environmental conditions. Geochim. Cosmochim. Acta 65, 1583-1599. doi: 10.1016/S0016-7037(00) 00629-3

Ward-Paige, C. A. (2014). "The role of the tourism industry," in Sharks: Conservation, Governance and Management, eds E. J. Techera and N. Klein (Milton Park: Routledge), 157-175.

Weng, K. C., Boustany, A. M., Pyle, P., Anderson, S. D., Brown, A., and Block, B. A. (2007a). Migration and habitat of white sharks (Carcharodon carcharias) in the eastern Pacific Ocean. Mar. Biol. 152, 877-894. doi: 10.1007/s00227-007-0739-4

Weng, K. C., O’Sullivan, J. B., Lowe, C. G., Winkler, C. E., Dewar, H., and Block, B. A. (2007b). Movements, behavior and habitat preferences of juvenile white sharks Carcharodon carcharias in the eastern Pacific. Mar. Ecol. Prog. Ser. 338, 211-224. doi: 10.3354/meps338211

Wetherbee, B. M., Lowe, C. G., and Crow, G. L. (1994). A review of shark control in Hawaii with recommendations for future research. Pac. Sci. 48, 95-115.

White, C. (2016). Quantifying the Habitat Selection of Juvenile White Sharks, Carcharodon carcharias, and Predicting Seasonal Shifts in Nursery Habitat Use. Masters Thesis, California State University, Long Beach, 58.

Whitney, N. M., Pratt, H. L. Jr., Pratt, T. C., and Carrier, J. C. (2010). Identifying shark mating behaviour using three-dimensional acceleration loggers. Endanger. Species Res. 10, 71-82. doi: 10.3354/esr00247

Whitney, N. M., White, C. F., Gleiss, A. C., Schwieterman, G. D., Anderson, P., Hueter, R. E., et al. (2016). A novel method for determining post-release mortality, behavior, and recovery period using acceleration data loggers. Fish. Res. 183, 210-221.

Conflict of Interest Statement: The authors declare that the research was conducted in the absence of any commercial or financial relationships that could be construed as a potential conflict of interest.

Copyright (c) 2018 Huveneers, Apps, Becerril-García, Bruce, Butcher, Carlisle, Chapple, Christiansen, Cliff, Curtis, Daly-Engel, Dewar, Dicken, Domeier, Duffy, Ford, Francis, French, Galván-Magaña, García-Rodríguez, Gennari, Graham, Hayden, Hoyos-Padilla, Hussey, Jewell, Jorgensen, Kock, Lowe, Lyons, Meyer, Oelofse, Oñate-González, Oosthuizen, O’Sullivan, Ramm, Skomal, Sloan, Smale, Sosa-Nishizaki, Sperone, Tamburin, Towner, Wcisel, Weng and Werry. This is an open-access article distributed under the terms of the Creative Commons Attribution License (CC BY). The use, distribution or reproduction in other forums is permitted, provided the original author(s) and the copyright owner(s) are credited and that the original publication in this journal is cited, in accordance with accepted academic practice. No use, distribution or reproduction is permitted which does not comply with these terms. 